UNIVERSIDADE DE SÃO PAULO

INSTITUTO DE QUÍMICA DE SÃO CARLOS

\title{
RELAÇÃO ENTRE EFICIÊNCIA FOTODINÂMICA, CITOTOXICIDADE E PROPRIEDADES MOLECULARES DE CORANTES PARA APLICAÇÃO EM TERAPIA FOTODINÂMICA
}

\author{
Suélen Tadéia Gasparetto Buck
}

Dissertação apresentada ao Instituto de Química de São Carlos, da Universidade de São Paulo para obtenção do título de Mestre em Ciências (Química Analítica)

Orientadora: Prof ${ }^{a}$. Dr ${ }^{a}$. Janice Rodrigues Perussi 
"Deus não disse que a viagem seria fácil, mas Ele disse que a chegada valeria a pena."

(Max Lucado) 


\section{AGRADECIMENTOS}

Agradeço primeiramente a Deus, que é a fonte de toda sabedoria, pela saúde, pelo dom da vida, por ter sempre estado comigo, me ajudando, me dando paciência, ânimo e forças para não desistir.

Agradeço a minha orientadora Prof ${ }^{\mathrm{a}}$. Dra . Janice Rodrigues Perussi pela paciência, incentivo e dedicação para que tornasse possível a conclusão deste trabalho.

Agradeço a Profa. Dra. Paula Homem de Mello da Universidade Federal do ABC pela ajuda nas minhas dúvidas e pela colaboração para que também tornasse possível a realização deste trabalho.

Agradeço ao Prof. Dr. Albérico B.F. da Silva do Grupo de Química Teoria do IQSC-USP pela ajuda e colaboração neste trabalho.

Agradeço a minha mãe, irmã e meu padrasto pelo apoio, compreensão, carinho e dedicação.

Agradeço ao melhor noivo do mundo, Bruno, pelo carinho, amor, compreensão, dedicação e principalmente por muitas vezes aguentar meu mau humor e minhas preocupações.

Agradeço aos meus queridos amigos Cláudia, Juliana, Janaina, Júlio e Roberta pelo carinho, pelas brincadeiras, pelos bons momentos e por sempre tornarem meu dia melhor.

Agradeço aos meus amigos de Araraquara, principalmente ao Tiago, Andreza, Hitan e Cacá, pela constante preocupação, amizade sincera e companheirismo.

A CNPq pelo apoio financeiro. 


\section{SUMÁRIO}

ÍNDICE DE FIGURAS

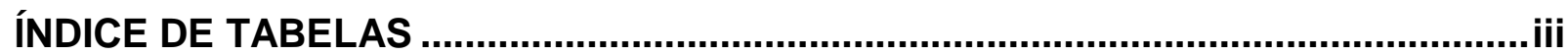

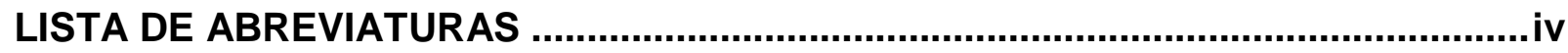

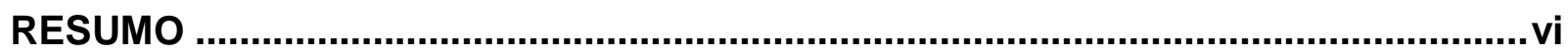

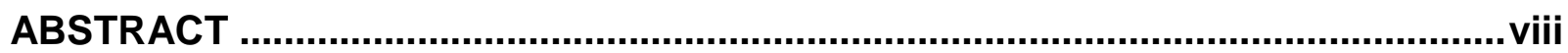

1. INTRODUÇÃO

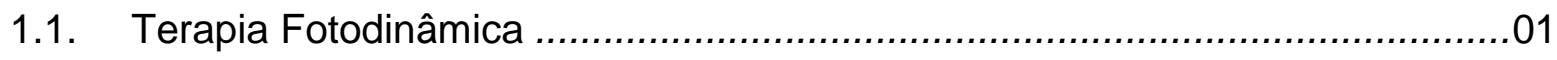

1.2. Mecanismos de fotossensibilização …………….......................................

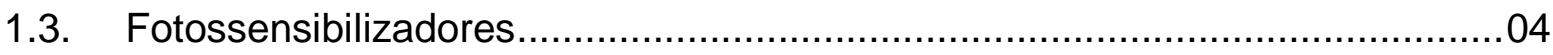

1.4. Transporte e localização dos fotossensibilizadores …………………...........10

1.5. Avaliação da eficiência dos fotossensibilizadores........................................12

1.6. Estudo teórico de fotossensibilizadores baseado em métodos de Química

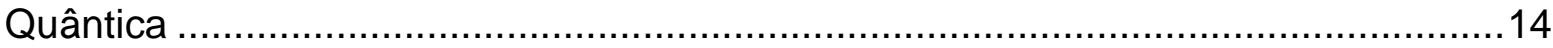

2. OBJETIVOS

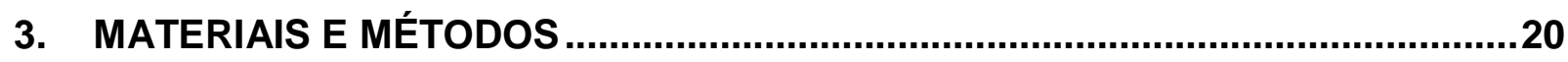

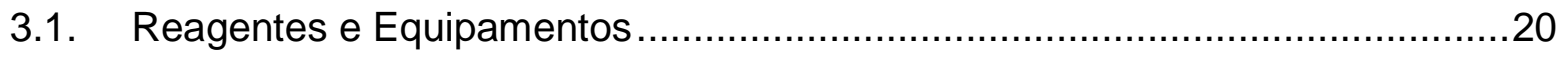

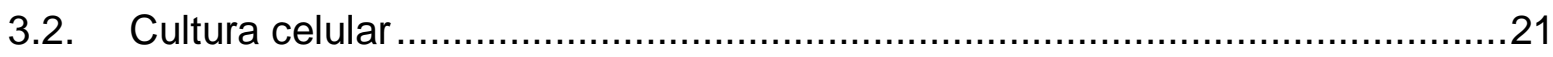

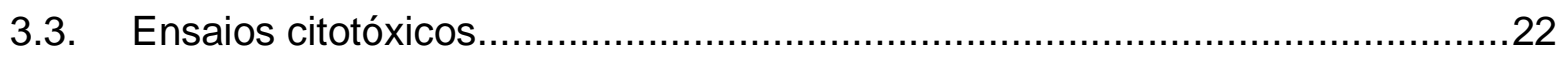

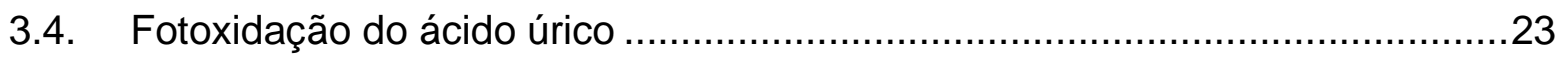


3.5. Interação dos fotossensibilizadores com albumina de soro bovino .25

3.6. Determinação do coeficiente de partição dos fotossensibilizadores .27

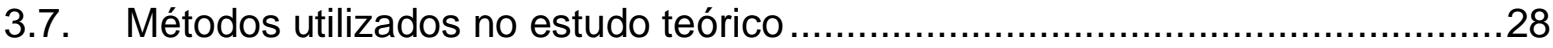

3.8. Cálculo da média amostral e do desvio padrão .......................................29

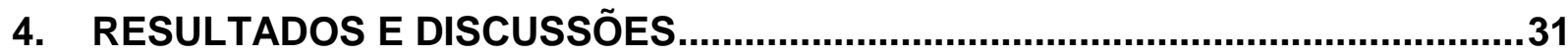

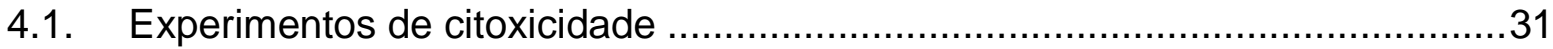

4.2. Experimento de fotoxidação do acido úrico .............................................34

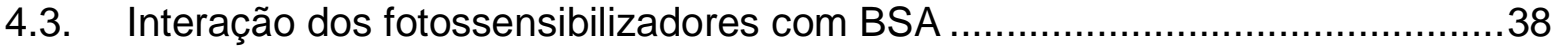

4.4. Determinação dos coeficientes de partição dos fotossensibilizadores ...........47

4.5. Estudo teórico dos fotossensibilizadores ................................................50

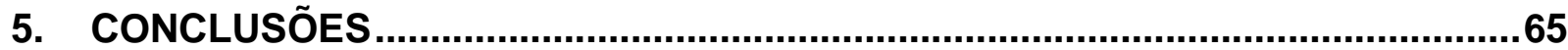

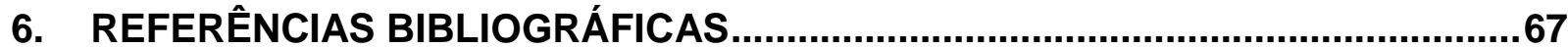




\section{ÍNDICE DE FIGURAS}

Figura 1. llustração gráfica dos mecanismos fotoquímicos e fotofísicos em PDT. .03

Figura 2. Estrutura química dos corantes Azul de Metileno e Azul de Toluidina O. ......07

Figura 3. Estrutura química dos corantes Eritrosina B, Eosina Y, Rose Bengal e Fluoresceína. 09

Figura 4. Esquema resumido de uma lipoproteína de baixa densidade. 11

Figura 5. Espectro de absorção ótica de uma solução de ácido úrico $(10 \mu \mathrm{g} / \mathrm{mL})$ em PBS, na ausência de corante. .35

Figura 6: Espectros de absorção ótica antes e depois de irradiação com LED de misturas contendo ácido úrico $(10 \mu \mathrm{g} / \mathrm{mL})$ e corante $(5 \mu \mathrm{g} / \mathrm{mL})$, em PBS. Os espectros de absorção ótica evidenciam a diminuição da banda em $292 \mathrm{~nm}$ devido a fotoxidação do ácido úrico. A linha vermelha ( - ) indica o espectro obtido após o tempo de irradiação e a linha preta ( - ) indica o espectro obtido antes da irradiação. 36

Figura 7. Espectro de absorção do BSA na ausência (0) e na presença de FS (1-13), a 25ํㅡ. Concentração de FS: (1) $0.25 \mu \mathrm{M}$, (2) $0.5 \mu \mathrm{M}$, (3) $0.75 \mu \mathrm{M}$, (4) $1.00 \mu \mathrm{M}$, (5) $1.25 \mu \mathrm{M}$, (6) $1.50 \mu \mathrm{M}$, (7) $1.75 \mu \mathrm{M}$, (8) $2.00 \mu \mathrm{M}$, (9) $2.25 \mu \mathrm{M}$, (10) $2.50 \mu \mathrm{M}$, (11) $2.75 \mu \mathrm{M}$, (12) $3.00 \mu \mathrm{M}$ e (13) $3.25 \mu \mathrm{M}$, respectivamente. Para todas as soluções, concentração de BSA: $2.00 \mu \mathrm{M}$. 39

Figura 8. Gráfico de $\mathrm{F}_{0} / \mathrm{F}$ em função de [FS], onde: $20^{\circ}, \bullet 25^{\circ}$ e $\Delta 35^{\circ}$. 40 
Figura 9. Espectro de absorção de BSA, FS, BSA-FS a $25^{\circ} \mathrm{C}$, onde (-) BSA-FS, (-) BSA e (-) FS. As concentrações de BSA e FS são 2.00 e $2.00 \mu \mathrm{M}$, respectivamente.

Figura 10. Gráfico de $\log \left(\left(\mathrm{F}_{0}-\mathrm{F}\right) / \mathrm{F}\right)$ versus $\log \left([\mathrm{FS} \mathrm{t}]-\mathrm{n}\left[\mathrm{BSA}_{\mathrm{t}}\right]\left(\mathrm{F}_{0}-\mathrm{F}\right) / \mathrm{F}_{0}\right)$ para a reação dos corantes com BSA, onde: $\quad 20^{\circ} \mathrm{C}, \bullet 25^{\circ} \mathrm{C}$ e $\triangle 35^{\circ} \mathrm{C}$. 45

Figura 11. Estruturas otimizadas e os eixos cartesianos para as moléculas estudadas. 51

Figura 12. Representações gráficas dos orbitais de fronteira para as moléculas estudadas. 56

Figura 13. Gráfico de atividade fotodinâmica em função de $I_{50}$ no claro para 6 hrs de incubação com células HEp-2, com corantes xantenos. 58

Figura 14. Cargas atômicas para as moléculas estudadas (átomos de hidrogênio omitidos) 63 


\section{ÍNDICE DE TABELAS}

Tabela 1: Citotoxicidade no claro e no escuro dos corantes fenotiazinicos na linhagem celular HEp-2 em função do tempo de irradiação e da dose de luz. A intensidade do LED utilizado nas irradiações foi de $11 \mathrm{~mW} \mathrm{~cm}^{-2}$, com $\mathrm{n}=7$.....32

Tabela 2: Citotoxicidade no claro e no escuro dos corantes xantenos na linhagem celular HEp-2 em função do tempo de incubação e da dose de luz de $18 \mathrm{~J} / \mathrm{cm}^{2}$. A intensidade do LED utilizado nas irradiações foi de $19 \mathrm{~mW} \mathrm{~cm}^{-2}$, com $\mathrm{n}=7 \ldots 33$

Tabela 3: Valores de atividade fotodinâmica obtidos para os corantes xantenos e fenotiazínicos, sendo que os valores apresentados são as médias dos valores obtidos em quatro experimentos. 37

Tabela 4. Valores de Ksv e Kq para a reação de BSA com cada um dos corantes em diferentes temperaturas, sendo $n=3$. 41

Tabela 5. Valores das constantes de ligação e dos números de sítios de ligação para os corantes com BSA nos diferentes valores de temperatura. 46

Tabela 6 - Valores dos logaritmos dos coeficientes de partição para cada corante. 48

Tabela 7. Propriedades obtidas por métodos teóricos para os corantes estudados......52

Tabela 8: Comparação dos valores de $\mathrm{IC}_{50}$ no claro para $4 \mathrm{~h}$ e $6 \mathrm{~h}$ de incubação em células HEp-2, dose de $18 \mathrm{~J} / \mathrm{cm}^{2}$ com os valores de energia dos orbitais de fronteira. 54 


\section{LISTA DE ABREVIATURAS}

AF Atividade Fotodinâmica

AM Azul de Metileno

ATO Azul de Toluidina $O$

AU Ácido Úrico

BSA Albumina de soro bovino (do termo em inglês: Bovine Serum Albumin)

DFT Teoria do funcional de densidade (do termo em inglês: density-functional theory)

ER Eritrosina B

EY Eosina $Y$

FDA do termo em inglês, Food and drug administration

FL Fluoresceína

FS Fotossensibilizador

HDL Lipoproteínas de alta densidade (do termo em inglês: high-density lipoproteins)

HEp-2 Linhagem celular tumoral de laringe humana

HF Hartree e Fock

HOMO Último orbital molecular ocupado (do termo em inglês: Highest orbital molecular occupied)

LDL Lipoproteínas de baixa densidade (do termo em inglês: low-density lipoproteins)

LED Diodos emissores de luz (do termo em inglês: light emitting diode)

LUMO Primeiro orbital molecular desocupado (do termo em inglês: Lowest orbital molecular unoccupied)

MTT Brometo de 3-(4,5 dimetil)tiazol-2-il-2,5-difenil tetrazólio

n Número de sítios de ligação

PBS Solução salina tamponada de fosfato (do termo em inglês: Phosphate Buffer Saline)

PDT Terapia fotodinâmica (do termo em inglês: Photodynamic Therapy)

RB Rose Bengal 
TD-DFT Teoria do funcional de densidade dependente do tempo (do termo em inglês: time-dependent density-functional theory) 


\section{RESUMO}

A terapia fotodinâmica consiste em uma nova e promissora técnica de tratamento de câncer. O tratamento se baseia na administração tópica ou sistêmica de um fotossensibilizador, que se acumula seletivamente em tecido tumoral. Na presença de luz e oxigênio o fotossensibilizador produz espécies tóxicas levando as células à morte.

Neste trabalho foi determinada a eficiência fotodinâmica dos corantes fenotiazínicos (Azul de Metileno e Azul de Toluidina O) e xantenos (Rose Bengal, Eritrosina B, Eosina Y e Fluoresceína) através da comparação dos valores de concentração inibitória media $\left(\mathrm{IC}_{50}\right)$ em células tumorais HEp-2; atividade fotodinâmica utilizando o ácido úrico como dosímetro químico; interação com proteína através da constante de ligação $\left(\mathrm{K}_{\mathrm{A}}\right)$ com BSA e coeficiente de partição em octanol-água $(\log P)$. Os resultados foram relacionados com as propriedades moleculares destes corantes afim de se obter uma melhor compreensão de suas estruturas e fornecer subsídios para o planejamento de novos e melhores compostos para serem utilizados como fotossensibilizadores em PDT.

Os experimentos mostraram que os fenotiazínicos são mais citotóxicos nesta linhagem celular do que os xantenos, sendo que o Azul de Toluidina O possui o menor valor de $\mathrm{IC}_{50}$. Dentre os xantenos, o Rose Bengal foi o fotossensibilizador mais eficiente em causar fotoxidação do ácido úrico e o Azul de Toluidina O dentre os fenotiazínicos. Estes resultados estão de acordo com os resultados obtidos nos experimentos citotóxicos, em que Rose Bengal e Azul de Toluidina $O$ apresentam os menores valores de $\mathrm{IC}_{50}$, em suas respectivas famílias. Os xantenos possuem maior interação com BSA do que os fenotiazínicos. Os corantes fenotiazínicos são mais hidrofóbicos do que os xantenos (com 
exceção do Rose Bengal), o que corrobora com os valores de $\mathrm{IC}_{50}$, pois também são os mais citotóxicos.

Relacionando algumas propriedades moleculares dos corantes obtidos no estudo teórico com os dados experimentais observou-se que; i) quanto menor os valores das energias dos orbitais $\mathrm{HOMO}$ e LUMO maior foi os valores obtidos de $\mathrm{IC}_{50}$; ii) os corantes fenotiazínicos são moléculas menores que os corantes xantenos, facilitando sua difusão pela membrana plasmática e a localização nas organelas; iii) nos corantes xantenos a substituição por um átomo de número atômico maior provoca aumento no valor da atividade fotodinâmica e iv) os xantenos apresentam momentos de dipolo maiores do que os fenotiazínicos, explicando assim a maior hidrofilicidade dos xantenos.

Os resultados obtidos mostraram que os corantes fenotiazínicos possuem uma eficiência fotodinâmica superior aos dos corantes xantenos, sendo que o Azul de Toluidina $\mathrm{O}$ é o mais eficiente e deve ser considerado como agente potencial para aplicação em PDT. 


\begin{abstract}
The photodynamic therapy consists in a new technique for cancer treatment. The treatment is based on topic or systemic administration of a photosensitizer, which is selectively retained in tumor tissue. In the presence of light and oxygen, it produces toxic species to cells leading to their death.

In this work it was determinated the photodynamic efficiency of phenothiazinium (Methylene Blue and Toluidine Blue O) and xanthene dyes (Rose Bengal, Erythrosin B, Eosin $\mathrm{Y}$ and Fluorescein) by comparing the values of medium inibitory concentration $\left(\mathrm{IC}_{50}\right)$ in HEp-2; photodynamic activity using the uric acid as a chemical dosimeter; interaction with protein through the binding constant $\left(\mathrm{K}_{\mathrm{A}}\right)$ with $\mathrm{BSA}$ and the octanolwater partition coefficient $(\log \mathrm{P})$. The results were related with the molecular properties of these dyes, in order to obtain a better understanding of their structures and provide insights for the design of new and better compounds to be used as photosensitizers in PDT.
\end{abstract}

The experiments showed that the phenothiazine dyes are more cytotoxic in this cell line than the xanthenes, being Toluidine Blue the one that has the lower $\mathrm{IC}_{50}$. Among the xanthenes, Rose Bengal was the most efficient photosensitizer in causing photoxidation of uric acid and the Toluidine Blue $\mathrm{O}$ among the phenothiazines. These results are consistent with the ones obtained in the cytotoxicity experiments, once the Rose Bengal and Toluidine Blue $\mathrm{O}$ have the lower $\mathrm{IC}_{50}$ values, when compared with the other dyes studied in the same family. The xathenes have higher interaction with BSA than the phenothiazines. The phenothiazine dyes are more hydrophobic than the 
xanthenes (with the exception of Rose Bengal), which corroborate with the $\mathrm{IC}_{50}$ values, once they are also the most cytotoxic.

Relating some molecular properties of the dyes obtained in the theoretical studies with the experimental data, it could be observed that; i) the lower is the values of HOMO and LUMO energy, the high is the $\mathrm{IC}_{50}$; ii) the phenothiazine dyes are smaller molecules than the xanthenes, which facilitate their diffusion across the plasmatic membrane and the localization in organelles; iii) in xanthenes dyes the substitution for an atom with higher atomic number increases the photodynamic activity, and iv) the xanthenes dyes have the higher dipole moment than the phenothiazines, explaining the higher hydrophilicity of the xanthenes.

The obtained results showed that the phenothiazine dyes have higher photodynamic efficiency than the xanthenes dyes, being Toluidine Blue the most efficient of these dyes and it should be considered as a potential agent for photodynamic therapy. 


\section{INTRODUÇÃO}

\subsection{Terapia Fotodinâmica}

O câncer é uma das principais causas de morte e sua incidência vem aumentando cada vez mais. Terapias tradicionais contra o câncer tais como cirurgia, destruição das células cancerígenas por substâncias tóxicas (quimioterapia) ou por radiação (radioterapia) freqüentemente são inadequadas por apresentar vários efeitos colaterais causados pela perda de função da célula normal devido à falta de seletividade destas terapias, além de não oferecer a recuperação total do paciente. Portanto, há necessidade de melhores métodos de tratamento da doença, que sejam mais eficazes e seletivos, obtendo-se deste modo menores efeitos colaterais ${ }^{1,2}$.

A Terapia Fotodinâmica (PDT, do inglês, Photodynamic Therapy) é um tratamento promissor que envolve a administração local ou sistêmica de um fotossensibilizador (FS) seguida de irradiação com luz visível de comprimento de onda compatível com a absorção do FS após um período de tempo no qual este se acumula preferencialmente nas células tumorais ${ }^{3-6}$. Assim, FS e luz na presença de oxigênio molecular gera espécies citotóxicas letais que são capazes de danificar componentes celulares como membranas ${ }^{7}$, proteínas $^{8}$ e ácidos nucléicos ${ }^{9}$, provocando a destruição irreversível da célula tumoral e possibilitando grande seletividade, pois somente as células que são expostas simultaneamente ao FS e luz sofrerão o efeito citotóxico ${ }^{3}$.

A PDT é um tratamento interessante para o câncer devido à seletividade dupla obtida pelo acúmulo preferencial do FS na célula tumoral e pela habilidade de confinar a ativação do FS a estas células através da restrição da iluminação àquela região 
específica $^{3,5}$. Portanto, comparado com os métodos atuais de tratamento, PDT possui a vantagem de ser um método mais efetivo e seletivo de destruição das células tumorais sem destruir as células vizinhas normais ${ }^{10}$. Além disso, PDT também possui aplicações não-oncológicas, sendo utilizada para tratamentos dermatológicos ${ }^{11}$ e na inativação de microrganismos, técnica conhecida como inativação fotodinâmica ${ }^{12-17}$.

Outra vantagem é que PDT é uma modalidade de tratamento minimamente invasiva, podendo ser aplicada repetidamente no mesmo local e ser usada no tratamento de vários tipos de câncer, incluindo aqueles que são resistentes as outras terapias. É importante observar que o uso da quimioterapia, radioterapia ou cirurgia não impedem a aplicação da PDT, estas podem ser usadas antes ou após o paciente ter sido submetido a PDT e vice-versa ${ }^{4,18}$.

\subsection{Mecanismos de fotossensibilização}

Após a absorção de um fóton, o FS é excitado do estado fundamental para o primeiro estado excitado singlete (spins opostos), este pode retornar ao estado fundamental através de transições radiativas (fluorescência) ou não-radiativas (conversão interna) entre estados de mesma multiplicidade, pode também ser convertido através do cruzamento intersistema ao estado excitado tripleto sofrendo inversão de spin. O estado tripleto possui tempo de vida longo o suficiente para permitir que o FS excitado interaja com as moléculas vizinhas de duas maneiras, definidas como mecanismos tipo I e tipo $\mathrm{II}^{20-24}$.

O mecanismo tipo I envolve a transferência de elétron ou abstração de um átomo de hidrogênio entre o FS excitado e um substrato, gerando radicais livres. Estes 
radicais podem reagir com oxigênio para formar espécies reativas tais como ânions superóxidos e radicais hidroxilas, estas espécies causam danos oxidativos produzindo lesões nas células ${ }^{20,22}$. No mecanismo tipo II o FS transfere sua energia diretamente para o oxigênio molecular no estado fundamental triplete, gerando oxigênio excitado singlete $^{21-23}$. A figura 1 ilustra graficamente o processo de absorção de luz pelo FS e transferência de energia.

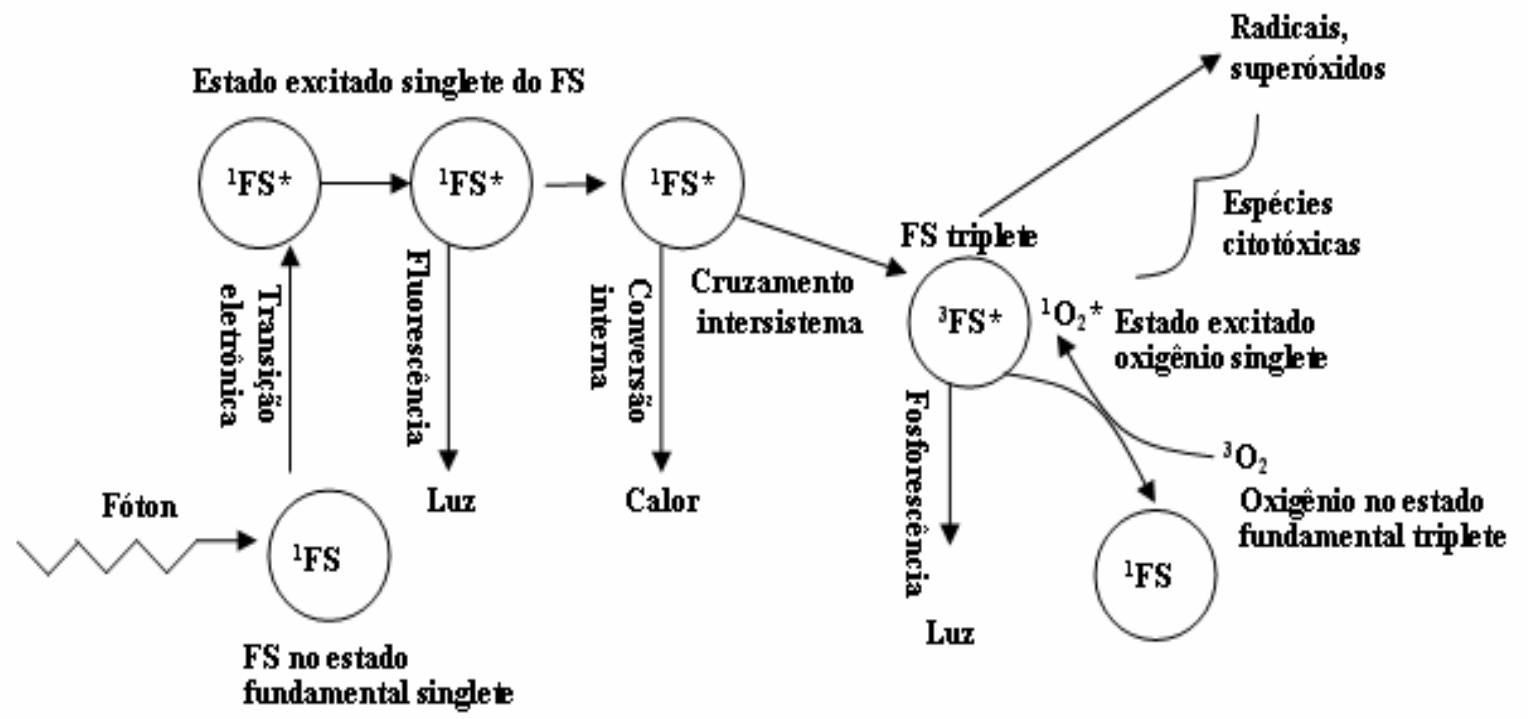

Figura 1. llustração gráfica dos mecanismos fotoquímicos e fotofísicos em $\mathrm{PDT}^{8}$.

O oxigênio singlete reage eficientemente com diferentes substratos biológicos com consequente dano oxidativo que pode causar a morte celular ${ }^{23-25}$. Devido a sua natureza altamente reativa, o oxigênio singlete possui raio de ação estimado em cerca de 0.01-0.02 $\mu \mathrm{m}$, correspondendo ao tempo de vida de 0.01-0.04 $\mu$ seg em sistemas biológicos, isto significa que o dano fotodinâmico causado por sua formação ocorre próximo à localização da molécula do FS durante a irradiação. Sendo assim, a 
localização subcelular do FS é extremamente importante, pois determina a localização inicial do dano e seu impacto para a célula ${ }^{25-27}$.

Embora seja aceito que o mecanismo tipo II é o que ocorre predominantemente durante a PDT e que o oxigênio singlete é o principal agente responsável pelos danos causados nas células tumorais ${ }^{3,22,23,26}$, as reações do tipo I se tornam importantes em baixas concentrações de oxigênio, sendo que os dois mecanismos produzem danos oxidativos causando a consequente destruição do tumor ${ }^{3}$.

A eficiência da PDT depende da natureza química do FS, da sua concentração e localização no momento da irradiação, da dose de luz total utilizada, do tempo entre a administração do fotossensibilizador e a irradiação, do tipo do tumor e do seu nível de oxigenação ${ }^{4,10}$.

\subsection{Fotossensibilizadores}

Como foi visto anteriormente o FS na presença de luz e oxigênio molecular produz espécies citotóxicas capazes de destruir a célula tumoral. No entanto, um composto deve possuir algumas propriedades específicas para que possa ser utilizado como fotossensibilizador $^{8,28-30:}$

- Características fotofísicas favoráveis;

- Ser quimicamente puro e ter composição constante e conhecida, pois compostos puros simplificam a interpretação da relação dose-resposta;

- Ter mínima toxicidade no escuro, não ser mutagênico nem carcinogênico e apresentar toxidez somente na presença de luz; 
- Acúmulo preferencial na célula tumoral (seletividade), evitando assim efeitos colaterais;

- Ser rapidamente eliminado do organismo induzindo assim uma baixa toxicidade sistêmica (farmacocinética favorável);

- Ser solúvel em água ou em solvente inofensivo e não apresentar agregação em meio biológico, pois isto reduz a eficiência fotodinâmica;

- Não provocar dor durante e após o tratamento, já que PDT geralmente não requer anestesia ou sedação pesada;

- Facilidade de obtenção em escala industrial com boa reprodutividade e custos reduzidos.

As características fotofísicas favoráveis associadas à fotosensibilização envolvem a excitação do FS do estado fundamental para o estado excitado singlete através da absorção de luz na região de 600-800 nm (conhecida como "janela terapêutica") e o cruzamento intersistema do estado excitado singlete ao estado excitado triplete ${ }^{20,29}$. Quanto maior o comprimento de onda da luz incidente maior é a penetração no tecido e o efeito terapêutico obtido ${ }^{18,28,31}$. Radiações de comprimento de onda menor sofrem maior espalhamento e são absorvidas por cromóforos endógenos, principalmente a hemoglobina, diminuindo a penetração de luz no tecido e as bandas de absorção em comprimentos de onda maiores que $800 \mathrm{~nm}$ além de serem absorvidas pela água não possuem energia suficiente para produzir oxigênio singlete $e^{9,29,31,32}$.

As interações do estado excitado triplete do FS com oxigênio endógeno nas células alvo ou com substratos biológicos produzem os efeitos citotóxicos desejados. Sendo assim, é extremamente importante que um FS possua alta reatividade 
fotoquímica, com alto rendimento do estado excitado triplete com tempo de vida longo o suficiente para que possa produzir eficientemente oxigênio singlete (alto rendimento quântico de formação de oxigênio singlete, $\Phi \Delta$ ) bem como outras espécies reativas de oxigênio ${ }^{3,20,29}$.

O Photofrin®, uma mistura complexa de monômeros, dímeros e oligômeros de porfirina, foi o primeiro composto a obter aprovação pela Food and Drug Administration (FDA) para ser usado em PDT para o tratamento de vários tipos de câncer. Apesar de seu sucesso clínico, este composto apresentou alguns efeitos colaterais como prolongada fotossensibilidade da pele e fraca absorção acima de $600 \mathrm{~nm}$, limitando seu uso em tumores mais profundos devido à fraca penetração da luz no tecido $25,28,29,33$. A busca por fotossensibilizadores quimicamente puros, com absorção de luz em comprimento de onda maiores e com a redução da fotossensibilidade da pele em comparação ao Photofrin® levou ao desenvolvimento e estudo de várias classes de compostos, como as clorinas, as bacterioclorinas e as ftalocianinas ${ }^{16}$.

Os corantes fenotiazínicos são moléculas catiônicas com estrutura fundamental composta por um sistema de anel aromático tricíclico planar, que constitui um sistema altamente conjugado, funcionando como o cromóforo destes compostos. Estas características estruturais conferem aos fenotiazínicos propriedades adequadas para uso em PDT, como intensa absorção na região de 620-660 nm, região do espectro útil em PDT por estar dentro da janela terapêutica requerida para a eficiente penetração da luz no tecido bem como considerável rendimento quântico de oxigênio singlete ${ }^{34-38}$. As pesquisas envolvendo o uso dos corantes fenotiazínicos em PDT tem sido predominantemente concentradas no Azul de Metileno e no Azul de Toluidina O (figura 2), que são compostos com estrutura química e propriedades físico-químicas similares, 
possuindo um átomo de nitrogênio no anel central capaz de aceitar prótons e dois átomos de nitrogênio que contribuem para a deslocalização da carga no cromóforo, estabilizando o cátion ${ }^{36,39}$.<smiles>CN(C)c1ccc2nc3ccc(N(C)C)cc3[s+]c2c1</smiles>

Azul de metileno<smiles>Cc1cc2nc3ccc(N(C)C)cc3[s+]c2cc1N</smiles>

Azul de Toluidina $O$

Figura 2. Estrutura química dos corantes Azul de Metileno e Azul de Toluidina $\mathrm{O}^{35}$.

O Azul de Metileno é capaz de induzir efeito fototóxico em uma variedade de células tumorais in vitro, incluindo células HeLa (adenocarcinoma cervical humano), adenocarcinoma mamário, sarcoma 180, carcinoma de bexiga de rato, carcinoma de bexiga humana, célula-T humana e linfoma de células $\mathrm{B}^{33,40}$. $\mathrm{O}$ Azul de Toluidina $\mathrm{O}$ também exibe fototoxicidade em células de carcinoma epidermóide das glândulas submaxilares humanas e em células HeLa ${ }^{40}$.

O Azul de Metileno também possui atividade fotodinâmica in vivo, mostrando-se muito eficiente quando administrado diretamente no tumor, sendo utilizado em câncer superficial de bexiga e câncer de esôfago inoperável ${ }^{38,41,42}$. No entanto, a aplicação clínica do Azul de Metileno tem sido limitada devido à ausência de eficiência in vivo quando sua administração é feita por via intravenosa. Em meio biológico, os fenotiazínicos possuem a tendência de serem reduzidos por enzimas celulares, NADH e 
$\mathrm{FADH}_{2}$, a forma reduzida ou Leuco Azul de Metileno é incolor e absorve luz somente na região ultra-violeta, sendo portanto de pouca utilidade para a aplicação em PDT $^{41,43-45}$.

Além de serem utilizados no tratamento contra o câncer, o Azul de Metileno e o Azul de Toluidina $O$ também são fotossensibilizadores eficientes na inativação de organismos patogênicos, incluindo vírus ${ }^{44,46}{\text {, } \text { bactérias }^{16,34,35,46,47} \text { e fungos }}^{17,48}$. O Azul de Metileno tem sido utilizado na descontaminação de plasma sangüíneo ${ }^{43,46,49}$ e também no tratamento de metemoglobinemia ${ }^{29,50}$ e psoríase ${ }^{38,49}$. O Azul de Toluidina O tem sido utilizado na inativação de patógenos da cavidade oral, tais como fungos e bactérias $^{16-17,44,51-53}$.

Os corantes xantenos são compostos aniônicos cíclicos com três anéis aromáticos em arranjo linear com um átomo de oxigênio no anel central. Alguns exemplos de xantenos são: Rose Bengal, Eosina Y, Eritrosina B e Fluoresceína (figura 3). Estes corantes também possuem algumas propriedades satisfatórias para a PDT, como considerável rendimento quântico de oxigênio singlete, baixo custo e intensa absorção de luz na região visível (500-570 nm), no entanto, por não absorverem em comprimento de onda adequado para máxima penetração de luz nos tecidos estes corantes são mais indicados para o tratamento de lesões superficiais ${ }^{54-56}$. 
<smiles>NC(=O)c1ccccc1-c1c2cc(Br)c(=O)c(Br)c-2oc2c(Br)c(O[N+](=O)[O-])c(Br)cc12</smiles>

Eosina $Y$<smiles></smiles>

Rose Bengal<smiles>NC(=O)c1ccccc1-c1c2ccc(=O)cc-2oc2cc(O[N+]([O-])O)ccc12</smiles>

Fluoresceina<smiles>N#Cc1ccccc1-c1c2cc(I)c(=O)c(I)c-2oc2c(I)c(O[N+](=O)[O-])c(I)cc12</smiles>

Eritrosina B

Figura 3. Estrutura química dos corantes Eritrosina B, Eosina $Y$, Rose Bengal e Fluoresceína ${ }^{49}$.

Rose Bengal é o corante xanteno mais utilizado, possui alto rendimento quântico de oxigênio singlete ${ }^{57-60}$; sendo capaz de causar danos in vitro em células epiteliais de córnea de coelho ${ }^{58}$ e células epiteliais do pigmento da retina ${ }^{61}$. No entanto, a aplicação clínica do Rose Bengal também tem sido limitada, pois ao ser administrado de maneira sistêmica é rapidamente acumulado no fígado e excretado antes que possa se acumular no tecido tumoral ${ }^{57,58,61}$. Este corante também tem sido utilizado topicamente em oftalmologia para diagnóstico e na inativação fotodinâmica de bactérias ${ }^{16,17,60,62}$.

Devido à baixa toxidez e alta fluorescência, a Fluoresceína é utilizada como um agente de visualização para doenças oftalmológicas ${ }^{50}$. A Eritrosina B e Eosina $Y$ possuem atividade fotodinâmica em bactérias e fungos ${ }^{16,17,55}$, sendo que a Eosina $Y$ também foi extensivamente aplicada na quantificação e coloração de proteínas ${ }^{63}$. 
Em relação ao uso terapêutico, estes corantes xantenos apresentados ainda necessitam de algumas mudanças estruturais que façam com que seu comprimento de absorção máximo se encontre dentro da janela terapêutica de 600-800 nm necessária para o tratamento em seres humanos ${ }^{55}$.

\subsection{Transporte e localização dos fotossensibilizadores}

A estrutura química do FS determina seu modo de interação com as vizinhanças, tanto in vitro quanto in vivo. A hidrofobicidade e carga do FS influenciam seu comportamento em solução in vitro, isto é, se permanecerá na forma agregada ou monomérica. Já in vivo a hidrofobicidade, natureza química das cadeias laterais e carga do FS determinará a extensão das interações com as proteínas do plasma, com o pH do tecido tumoral e sua localização no mesmo ${ }^{64}$.

Já foi mencionado que devido ao pequeno raio de ação e curto tempo de vida do oxigênio singlete, a estrutura celular na qual o FS estiver ligado ou que estiver próxima do FS será preferencialmente danificada no processo de iluminação. De fato, a localização do FS em diferentes organelas ou em outras subestruturas celulares é relacionada com sua fototoxicidade total e com os mecanismos de morte celular ${ }^{64,65}$. A membrana plasmática, lisossomos, mitocôndria e citoplasma são componentes celulares onde o FS pode se localizar $8,33,61,64$

In vivo, os fotossensibilizadores podem se ligar tanto à albumina quanto às lipoproteínas do plasma ${ }^{64,66}$, onde o principal mecanismo de transporte do FS até o tecido tumoral é realizado através das lipoproteínas de baixa densidade (LDL) ${ }^{64,65,67}$. A LDL é a principal lipoproteína carregadora de colesterol no plasma humano, contendo 
cerca de $2 / 3$ do colesterol total do plasma, cada molécula de LDL contém aproximadamente 1500 moléculas de colesterol esterificado (éster colesteril) rodeada por uma monocamada fosfolipídica, colesterol livre e apoproteína-B (figura 4), sendo que as células podem suprir suas necessidades por colesterol através da endocitose de LDL por meio de receptores encontrados em sua superfície ${ }^{68,69}$.

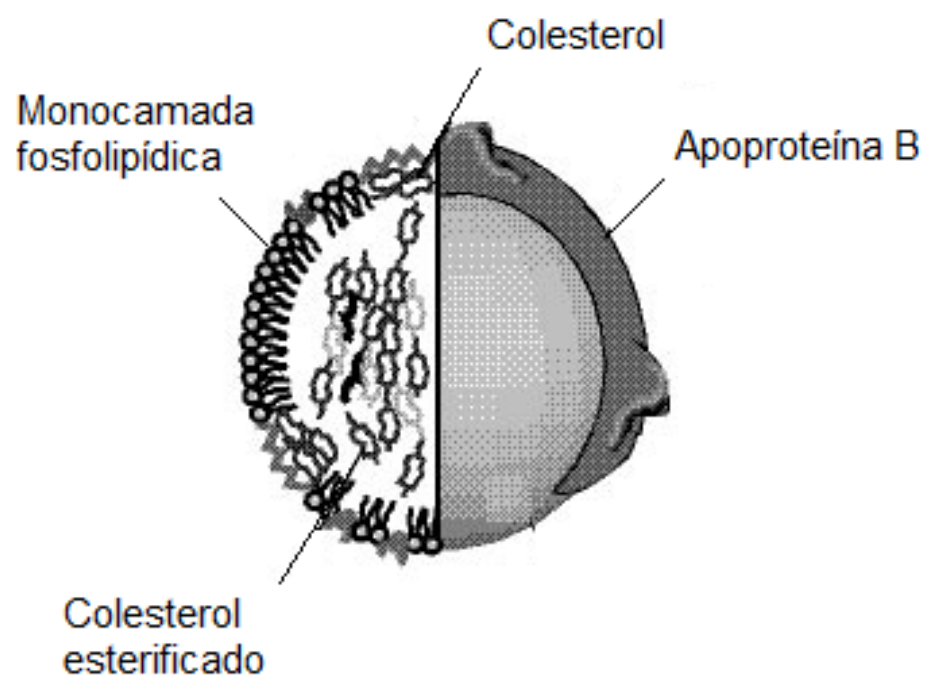

Figura 4. Esquema resumido de uma lipoproteína de baixa densidade ${ }^{\natural 8}$.

As moléculas de LDL também podem agir como transportadores naturais de FS, pois as células tumorais possuem elevado número de receptores LDL em comparação com as células normais devido ao aumento na velocidade de proliferação, necessitando de uma maior quantidade de colesterol ${ }^{66,70,71}$. O transporte e acúmulo de FS também podem ocorrer através de ligações com lipoproteínas de alta densidade (HDL) e albumina em processos que não envolvem receptores celulares ${ }^{64,70}$. O transporte e acúmulo do FS através de lipoproteínas é governado principalmente pelo caráter hidrofílico ou lipofílico dos fotossensibilizadores, sendo que fotossensibilizadores 
relativamente hidrofílicos são transportados pela albumina e globulinas e os mais hidrofóbicos ligam-se preferencialmente às lipoproteínas. No entanto, outros fatores além da hidrofobicidade podem favorecer a interação entre o FS e a LDL, tais como a distribuição assimétrica de cargas ${ }^{66-68,71}$.

$\mathrm{O} \mathrm{pH}$ de tecidos tumorais geralmente é menor em comparação ao de tecidos normais. $\mathrm{O} \mathrm{pH}$ de um tecido muscular humano normal é em torno de 7,10 a 8,06, enquanto que em tecido tumoral humano varia de 5,85 até 7,68. Esta característica pode favorecer o acúmulo preferencial de fotossensibilizadores que são aniônicos em $\mathrm{pH}$ fisiológico, pois são neutralizados eletronicamente tornando-se, portanto, mais lipofílicos e difundindo através da membrana plasmática da célula tumoral ${ }^{65,66,70,72}$.

\subsection{Avaliação da eficiência dos fotossensibilizadores}

No processo de planejamento e síntese de fotossensibilizadores mais eficazes ou na otimização dos já existentes, alguns fatores devem ser levados em consideração, tais como a interação do FS com proteínas do plasma, rendimento quântico de oxigênio singlete e lipofilicidade de sua estrutura molecular.

A albumina é a proteína mais abundante no plasma sanguíneo humano, muitos compostos, incluindo FS, ligam-se reversivelmente e com alta afinidade à albumina ${ }^{70,73}$. Esta ligação reversível prolonga o tempo de vida do FS no plasma, mas também diminui a concentração de FS livre para a ação fisiológica, sendo esta ligação importante principalmente para compostos que são insolúveis no plasma. Por outro lado, se a ligação for muito forte e a liberação do composto for muito lenta, a ação do 
FS será seriamente limitada, por esta razão é muito importante conhecer a afinidade de qualquer FS pela albumina ${ }^{70}$.

A albumina de soro bovino (BSA) tem sido utilizada para estudos de interação, pois já foi extensivamente caracterizada e possui função no transporte e armazenamento de compostos nos vertebrados ${ }^{73,74}$. A proteína BSA contém 582 resíduos de aminoácidos, possui dois triptofanos nas posições 134 e 212 bem como tirosina e fenilalanina ${ }^{63}$. Este composto também possui fluorescência intrínseca devido principalmente aos resíduos de triptofano, o qual pode emitir luz em cerca de $340 \mathrm{~nm}$ quando excitado por luz de comprimento de onda no ultravioleta por volta de $280 \mathrm{~nm}$. Visto que a fluorescência intrínseca da proteína geralmente é suprimida pela ligação com os fotossensibilizadores, este comportamento espectroscópico provê uma maneira de se estudar as interações entre estes compostos com a albumina ${ }^{63,74-77}$.

Como foi mencionado acima, na otimização de fotossensibilizadores alguns fatores devem ser levados em consideração, entre eles o rendimento quântico de oxigênio singlete $(\Phi \Delta)$, pois sua produção está intimamente relacionada com a eficiência do mecanismo Tipo II. Uma maneira de se avaliar o $\Phi \Delta$ é através da eficiência da fotoxidação do ácido úrico (AU) pelo FS. O ácido úrico é um conhecido supressor de oxigênio singlete ${ }^{78,79}$, podendo ser utilizado como um dosímetro químico para a determinação da atividade fotodinâmica (AF) para os diferentes tipos de fotossensibilizadores utilizados em PDT. Em um método proposto por Fischer et.al. a atividade fotodinâmica é calculada levando-se em conta o decréscimo na absorbância característica do ácido úrico em 292 nm na presença de um FS ativado pela luz ${ }^{76,77,80,81}$. A resposta biológica produzida por compostos bioativos (neste caso um FS) está diretamente relacionada com os mecanismos de absorção, distribuição e atividade 
intrínseca ${ }^{82}$. Os processos de absorção e distribuição são regulados pelo caráter lipofílico/hidrofílico do composto uma vez que é necessária a capacidade de interação com dois meios diferentes, lipofílico (membranas celulares) e hidrofílico (citoplasma), para que seja alcançado o alvo desejado ${ }^{44,47,55,82-84}$. Um modelo aceito para a primeira etapa da ação de um fármaco (transporte até o sítio de ação) é a habilidade do composto de se particionar entre 1-octanol, que simula uma membrana celular, e água, que simula o citoplasma. O solvente 1-octanol possui uma longa cadeia alquila saturada e um grupo hidroxila que faz ligações hidrogênio e embora seja imiscível em água, possui a capacidade de dissolver até $2.3 \mathrm{M}$ de água sob condições de equilíbrio. Esta combinação de cadeia lipofílica, grupo hidrofílico e moléculas de água conferem ao 1 octanol propriedades muito parecidas com as das membranas celulares ${ }^{82,83}$. O coeficiente de partição determinado em 1-octanol/água reflete apenas as interações hidrofóbicas, sendo, portanto um método rápido, simples e eficaz na avaliação da hidrofobicidade dos fotossensibilizadores utilizados.

Nosso grupo tem proposto ${ }^{76,77}$ a combinação destes métodos como uma maneira de investigar a eficiência fotodinâmica de fotossensibilizadores.

\subsection{Estudo teórico de fotossensibilizadores baseado em métodos de Química Quântica}

Em mecânica quântica, uma espécie química é considerada como sendo um conjunto de núcleos e elétrons que é caracterizado por funções de onda, $\psi_{i}$ (autofunções) e por suas respectivas energias, $E_{\mathrm{i}}$. Os métodos utilizados são basicamente três: ab initio, teoria do funcional de densidade (DFT) e semi-empíricos. O 
método $a b$ initio não faz uso dos parâmetros experimentais, embora forneça informações mais precisas sobre o comportamento químico. Em termos operacionais é mais lento e mais caro. Este fator estimulou o surgimento de métodos semi-empíricos, que se baseiam em algumas suposições que servem para simplificar os cálculos fazendo uso de alguns parâmetros obtidos experimentalmente ${ }^{85}$. Os métodos baseados no DFT podem ser considerados como sendo métodos intermediários aos ab initio e semi-empíricos em relação ao tempo computacional e ao tamanho de sistema que pode ser tratado: embora não se utilize de parâmetros experimentais, ao invés de tratar todos os elétrons, baseia-se na densidade eletrônica, o que simplifica as equações a serem resolvidas.

O ponto de partida de todo trabalho de mecânica quântica é a equação de Schröndinger, escrita da seguinte forma ${ }^{86}$ :

$$
\hat{H} \Psi=E \Psi
$$

O termo $\hat{H}$, operador hamiltoniano, é um operador que permite obter informações sobre a energia do sistema. Esta equação apresenta solução exata somente para o átomo de hidrogênio. Para resolvê-la para átomos multieletrôicos e moléculas, recorrese a aproximações. Dentre elas, pode-se citar a aproximação de Born-Oppenheimer que considera os núcleos como sendo "congelados", ou seja, como os núcleos são mais pesados que os elétrons, pode-se dizer que estão fixos, então é possível resolver a equação de Schrödinger para uma função de onda dependente apenas da posição dos elétrons ${ }^{86}$. No entanto, esta aproximação só pode ser aplicada a sistemas monoeletrônicos. Sendo assim, Hartree e Fock (HF) propuseram considerar o 
movimento dos elétrons isoladamente. Entretanto, os métodos baseados na aproximação HF envolvem um elevado número de integrais e, conseqüentemente, um elevado tempo computacional e restrições ao tamanho dos sistemas que podem ser $\operatorname{tratados}^{87}$.

Para diminuir os inconvenientes deste método pode-se desprezar um determinado número de integrais, ou utilizar um potencial interno ou ainda substituir uma grande parte das integrais por parâmetros empíricos e utilizar expressões aproximadas que incluem esses parâmetros para avaliar o restante das integrais. Estes são os métodos semiempíricos ${ }^{85}$.

Em contraste com os métodos semi-empíricos, o hamiltoniano na DFT é bem definido e suas características não são obscurecidas por freqüentes e injustificáveis aproximações no procedimento computacional. Nas derivações das equações do DFT, nenhum parâmetro em princípio necessita ser ajustado ou determinado empiricamente, podendo ser considerado, sob este aspecto, como uma teoria de natureza ab initio. A grande vantagem da metodologia da DFT sobre os métodos ab initio padrões está no ganho em velocidade computacional e espaço em memória. Sendo assim, este método é particularmente útil no estudo de grandes sistemas moleculares, descrevendo-se realisticamente diversos tipos de sistemas químicos, principalmente aqueles fora do alcance de métodos de natureza ab initio padrões ${ }^{88}$.

Na literatura, são encontrados estudos teóricos baseados em química quântica para diversos corantes. Nos últimos anos, os métodos semi-empíricos CNDO/S e ZINDO têm sido empregados para prever o comportamento espectral de diversos corantes $^{89,90}$. Além disso, o método baseado na teoria do funcional de densidade dependente do tempo (TD-DFT) também vem sendo utilizado para calcular as energias 
de excitação de alguns corantes ${ }^{91,92}$. No caso específico do azul de metileno, alguns estudos foram realizados utilizando diferentes métodos: MNDO, AM1, PM3, PPP e DFT, buscando analisar variações na geometria e no calor de formação em relação a outros corantes $^{89}$, explicar a interação com surfactantes aniônicos ${ }^{90}$ e com outras moléculas de corante (formação de dímeros) ${ }^{91}$. 


\section{OBJETIVOS}

Visando investigar a relação entre as características moleculares de uma série de fotossensibilizadores com uso potencial em Terapia Fotodinâmica e sua adequação à técnica, os parâmetros experimentais dos fotossensibilizadores relativos a eficiência fotodinâmica foram obtidos e analisados à luz das propriedades eletrônicas, estéricas, hidrofóbicas e topológicas calculadas para seis corantes através de métodos de Química Quântica em colaboração com a Prof. Dr. Paula Homem de Mello da Universidade Federal do ABC e com o Prof. Dr. Albérico B.F. da Silva do Grupo de Química Teoria do IQSC-USP.

Foram utilizados como modelo os corantes xantenos: Rose Bengal, Eosina Y, Fluoresceina e Eritrosina B e os corantes fenotiazínicos: Azul de Metileno e Azul de Toluidina O. O trabalho consistiu de três fases:

1. Determinação da eficiência fotodinâmica dos corantes através da obtenção dos seguintes parâmetros: concentração inibitória media $\left(\mathrm{IC}_{50}\right)$ em células tumorais; atividade fotodinâmica $(A F)$ utilizando o ácido úrico (AU) como dosímetro químico; coeficiente de partição em octanol-água $(\log P)$ para obter informações sobre a hidrofobicidade dos fotossensibilizadores, e interação com proteína através da determinação da constante de ligação $\left(\mathrm{K}_{\mathrm{A}}\right)$ com BSA usada como modelo.

2. Partindo das estruturas otimizadas dos compostos, foram calculadas as propriedades eletrônicas, estéricas, hidrofóbicas $(\log \mathrm{P})$ e topológicas para 
determinar teoricamente quais as características que discriminam os compostos com maior ou menor eficiência fotodinâmica.

3. Relação entre os resultados obtidos nos estudos teóricos com os resultados experimentais de determinação dos quatro parâmetros $\left(\mathrm{IC}_{50}, \mathrm{AF}, \log \mathrm{P}\right.$ e $\left.\mathrm{K}_{\mathrm{A}}\right)$. 


\section{MATERIAIS E MÉTODOS}

\subsection{Reagentes e Equipamentos}

Os corantes Rose Bengal (RB), Eosina Y (EY), Eritrosina B (ER), Fluoresceína (FL), Azul de Metileno (AM) e Azul de Toluidina O (ATO) foram adquiridos da SigmaAldrich $^{\circledR}$. As soluções estoque destes compostos foram preparadas em solução salina tamponada com fosfato (PBS) $\mathrm{pH} 7,4$ e mantidas a $4^{\circ} \mathrm{C}$ e ao abrigo de luz. Para os ensaios citotóxicos estas soluções foram diluídas em meio de cultura ISCOV'S (SigmaAldrich $^{\circledR}$ ) com $10 \%$ de soro fetal bovino e antibióticos penicilina $10.000 \mathrm{Ul} / \mathrm{mL}$ e estreptomicina $10 \mathrm{mg} / \mathrm{mL}$. As soluções foram esterilizadas por filtração em membrana de 0,22 $\mu \mathrm{m}$ (Millex GV-Millipore) imediatamente antes do uso.

As medidas de absorção ótica foram realizadas no espectrofotômetro HITACHI U-2800, utilizando-se cubeta de quartzo Hellma com as quatro faces polidas e $1,0 \mathrm{~cm}$ de caminho ótico. Os espectros de absorção ótica foram monitorados na faixa de 200$700 \mathrm{~nm}$.

As medidas de fluorescência foram realizadas no espectrofluorímetro HITACHI F4500, utilizando-se cubeta de quartzo Hellma com as quatro faces polidas e $1,0 \mathrm{~cm}$ de caminho ótico. Os espectros de fluorescência foram monitorados na faixa de 200-550 $\mathrm{nm}$.

Para a realização das irradiações foram utilizados diodos emissores de luz (LED) emitindo em comprimento de onda de $532 \mathrm{~nm}$ (verde) e $628 \mathrm{~nm}$ (vermelho) com intensidade de 19 e $11 \mathrm{~mW} / \mathrm{cm}^{2}$, respectivamente, refrigerados à água, desenvolvidos pelo Grupo de Óptica do Instituto de Física de São Carlos/USP. 


\subsection{Cultura celular}

A linhagem de células tumorais de laringe humana (HEp-2, ATCC-CCL-23) foi utilizada nos ensaios de fototoxicidade. Esta linhagem cresce em monocamada, aderida ao substrato sólido (garrafa de polipropileno - Corning), sendo cultivada em meio de cultura ISCOV'S com $10 \%$ de soro fetal bovino e antibióticos ${ }^{93}$. As células são mantidas em estufa (Forma Scientific), a $37^{\circ} \mathrm{C}, 95 \%$ de ar e $5 \%$ de $\mathrm{CO}_{2}$. Todo o manuseio com as células é feito com material estéril e sob fluxo laminar (Veco) para evitar a contaminação da cultura celular.

O subcultivo celular é feito através da adição de enzimas proteolíticas, neste caso a tripsina, para digerir as proteínas da matriz extracelular, desagregando as células do substrato sólido ${ }^{94}$. A tripsina pode ser prejudicial às células, portanto meio de cultura é adicionado logo a seguir e a suspensão é centrifugada (Excelsa II - Forma) a 1000 rpm por 1 min para que as células se precipitem e o sobrenadante seja descartado. Em seguida as células são solubilizadas em cerca de $2 \mathrm{~mL}$ de meio de cultura ${ }^{95,96}$.

Para quantificar a proporção de células vivas, é feito um teste de exclusão do corante, que é baseado no rompimento da integridade da membrana determinado pela captação de um corante para o qual a membrana da célula normalmente é impermeável (no caso o "trypan blue" $0.4 \%$ ). Para isso é retirada uma alíquota de $100 \mu \mathrm{L}$ da solução contendo as células e mistura-se com $400 \mu \mathrm{L}$ de meio de cultura e $500 \mu \mathrm{L}$ de solução de "trypan blue" para contagem de células utilizando-se uma câmara de Newbauer sob microscópio (CH2-Olympus). As células mortas tornam-se coloridas e as células vivas 
permancecem incolores, a razão entre o número de células vivas e mortas fornece a viabilidade celular ${ }^{97,98}$.

A suspensão de células é então distribuída nas garrafas de polipropileno com adição de meio de cultura e levadas novamente à estufa para o cultivo.

\subsection{Ensaios citotóxicos}

Para os ensaios citotóxicos utilizou-se uma concentração de $1 \times 10^{5}$ células $/ \mathrm{mL}$ em meio de cultura ISCOV'S com $10 \%$ de soro fetal bovino e antibióticos para o plaqueamento em placas de 96 poços (Corning). Estas placas foram mantidas em estufa a $37^{\circ} \mathrm{C}$ por $24 \mathrm{~h}$. As células foram então incubadas com diferentes faixas de concentração de cada corante por diferentes intervalos de tempo. Após esse período o meio de cultura contendo o corante foi removido, as células foram lavadas com cerca de $150 \mu \mathrm{L}$ de PBS pH 7,4 e adicionou-se meio de cultura. Para medir a fototoxicidade,

as placas foram irradiadas no comprimento de onda adequado para cada FS. Experimentos controle foram realizados para verificar a dependência da citotoxicidade dos fotossensibilizadores não irradiados em função do tempo de incubação com as células tumorais. Em seguida, as células foram incubadas em estufa por mais $48 \mathrm{~h}$. Esse intervalo é considerado ideal para o encerramento de ensaios de sobrevivência após tratamento fotodinâmico, já que tempos de incubação menores podem ser insuficientes para que as células se recuperem totalmente do tratamento a que foram submetidas e intervalos maiores podem acarretar um aumento muito grande no número de células, dificultando a contagem ${ }^{95}$. 
Para avaliar a viabilidade celular e então calcular a porcentagem de toxicidade, foi realizado o ensaio com 3-(4,5-dimetil) tiazol-2-il-2,5-difenil brometo de tetrazólio (MTT) obtido da Sigma-Aldrich ${ }^{\circledR}$. Este é um método colorimétrico rápido que envolve a redução de MTT, que é amarelo, a um produto azul de formazam que absorve em 570 nm. A redução é feita pelas dehidrogenases mitocondriais das células vivas e ocorre se as células têm um nível significativo de metabolismo oxidativo ${ }^{99}$. Após a adição de MTT, as células foram incubadas por 3h na estufa. Após esse período o meio de cultura com MTT foi removido, tendo cuidado para não danificar os cristais de formazam formados. Adicionou-se então $50 \mu \mathrm{L}$ de etanol puro e $150 \mu \mathrm{L}$ de uma solução 1:1 de PBS e isopropanol, para solubilizar os cristais. A absorbância é então lida no leitor de células Benchmark-BIO-RAD e os resultados apresentados por meio de gráficos de sobrevivência celular (\%) em função da concentração do fotossensibilizador. Utilizou-se o programa CalcuSyn para a obtenção dos valores de $\mathrm{IC}_{50}{ }^{100}$.

\subsection{Fotoxidação do ácido úrico}

Neste método proposto por Fischer et al. ${ }^{81}$, o ácido úrico $\left(\right.$ Sigma-Aldrich $^{\circledR}$ ) é usado como um dosímetro químico. Quando uma mistura de AU e FS é irradiada, a banda de absorção característica do AU em $292 \mathrm{~nm}$ decresce e fornece assim uma rápida avaliação da atividade fotodinâmica do FS. Neste experimento foi investigado o decréscimo da banda de absorção do AU na presença dos corantes xantenos e fenotiazínicos, a fim de se obter a atividade fotodinâmica de cada um. 
Uma amostra contendo $10 \mu \mathrm{g} / \mathrm{mL}$ de AU e $5 \mu \mathrm{g} / \mathrm{mL}$ de FS foi irradiada com LED verde de intensidade $190 \mathrm{~W} / \mathrm{m}^{2}$ para os corantes xantenos e vermelho de intensidade $110 \mathrm{~W} / \mathrm{m}^{2}$ para os fenotiazínicos, durante $360 \mathrm{~s}$, sob agitação suave. Antes e após a irradiação foram obtidos espectros de absorção da amostra, determinando-se desta forma a diferença na intensidade de absorção do ácido úrico em 292 nm em ambos os espectros. As análises foram realizadas em triplicata.

Uma vez que existe uma correlação linear entre esse decréscimo na banda de absorção do AU e sua supressão pelo ${ }^{1} \mathrm{O}_{2}$ é possível obter o coeficiente de atividade fotodinâmica (AF) para cada FS através da seguinte equação:

$$
A F=\frac{\Delta A_{A U} \times 10^{5}}{E_{0} \times t \times A_{F S(\lambda i r r)}}
$$

Onde:

$\mathrm{AF}=$ atividade fotodinâmica $\left(\mathrm{m}^{2} \mathrm{Ws}=\mathrm{m}^{2} / \mathrm{J}\right)$

$\Delta A_{A U}=$ decréscimo da absorbância do acido úrico em 292 nm antes e após a irradiação

$$
\begin{aligned}
& \mathrm{E}_{0}=\text { intensidade de luz }\left(\mathrm{W} / \mathrm{m}^{2}\right) \\
& \mathrm{t}=\text { tempo de irradiação }(\mathrm{s})
\end{aligned}
$$

$A_{F S(\text { (ir) }}=$ absorbância do fotossensibilizador na solução no comprimento de onda de irradiação (532 nm, LED verde e 628 nm, LED vermelho). 


\subsection{Interação dos fotossensibilizadores com albumina de soro bovino}

A interação do FS com BSA foi avaliada através da supressão da fluorescência do triptofano presente no BSA, na presença de um FS. Supressão de fluorescência se refere a qualquer processo que diminua a fluorescência intrínseca de uma amostra, sendo uma ferramenta importante na análise da interação entre proteína e um supressor, sendo que este processo pode ocorrer de duas maneiras: estática e dinâmica. No processo de supressão estática ocorre a formação de um novo complexo fluoróforo-FS e geralmente é afetado pela temperatura, cujo aumento induz ao decréscimo da extensão da supressão da fluorescência e a formação do novo complexo geralmente provoca mudanças no espectro de absorção. No processo de supressão dinâmica ocorre a interação do FS com a molécula no estado excitado do fluoróforo, o aumento da temperatura resulta no aumento da velocidade de difusão da molécula e consequentemente na constante de velocidade de supressão. Estes dois tipos de supressão podem ser distinguidos através da comparação dos valores de $\mathrm{K}_{\mathrm{SV}}$ (constante de Stern-Vomer) em diferentes temperaturas e dos espectros de absorção na presença e na ausência do $\mathrm{FS}^{63,75}$. Os valores de $\mathrm{K}_{\mathrm{Sv}}$ para a interação do BSA com os FS foram obtidos através da equação de Stern-Vomer abaixo ${ }^{01}$.

$$
\frac{F_{0}}{F}=1+K_{q} \tau_{0}[F S]=1+K_{S V}[F S]
$$

Onde:

$F_{0}=$ intensidade de fluorescência em $340 \mathrm{~nm}$ do BSA na ausência do FS 
$\mathrm{F}=$ intensidade de fluorescência em $340 \mathrm{~nm}$ do BSA na presença do FS

$\mathrm{K}_{\mathrm{q}}=$ constante de velocidade de supressão bimolecular

$\tau_{0}=$ tempo de vida médio do fluoróforo na ausência do FS e seu valor é $10^{-8} \mathrm{~s}{ }^{102}$.

[FS] $=$ concentração do FS

$\mathrm{K}_{\mathrm{SV}}=$ constante de supressão dinâmica de Stern-Volmer, relacionada com 0 processo de colisão bimolecular

Para a determinação da constante de ligação e do número de sítios de ligação, foi utilizada a equação abaixo, válida se a supressão for um processo estático ${ }^{73}$ :

$$
\log \left(\frac{F_{0}-F}{F}\right)=n \log K_{A}+n \log \left(\left[F S_{t}\right]-n\left[B S A_{t}\right] \frac{F_{0}-F}{F_{0}}\right)
$$

(Equação 4)

Onde:

$F_{0}$ e $F=$ intensidades de fluorescência do BSA em $340 \mathrm{~nm}$, na ausência e na presença de FS, respectivamente

$\mathrm{n}$ = número de sítios de ligação

$\mathrm{K}_{\mathrm{A}}=$ constante de ligação

$\left[\mathrm{FS}_{\mathrm{t}}\right]$ e $\left[\mathrm{BSA}_{\mathrm{t}}\right]=$ concentrações totais do $\mathrm{FS}$ e BSA na solução, respectivamente

Foram preparadas soluções contendo FS em treze diferentes concentrações e BSA na concentração fixa de $2 \mu \mathrm{M}$. Estas soluções foram agitadas e deixadas em repouso no escuro durante 20 min para promover a formação do complexo fluoróforo- 
BSA. Os espectros de fluorescência e absorção foram obtidos e utilizados na determinação das constantes mencionadas acima. As medidas de fluorescência foram realizadas com comprimento de onda de excitação em $280 \mathrm{~nm}$, com fenda de excitação e emissão de $2.5 \mathrm{~nm}$. As medidas foram feitas em triplicata para cada corante.

\subsection{Determinação do coeficiente de partição dos fotossensibilizadores}

O logaritmo do coeficiente de partição foi utilizado como uma medida do caráter lipofílico dos corantes, calculado de acordo com o método proposto por Pooler e Valenzeno ${ }^{103}$. PBS e 1-octanol foram utilizados como solventes imiscíveis, cada um présaturado com o outro. Foram preparadas soluções contendo $3 \mu \mathrm{g} / \mathrm{mL}$ dos corantes em PBS, transferiu-se $10 \mathrm{~mL}$ de cada uma dessas soluções individualmente para um tubo com a adição de igual volume de 1-octanol. As soluções foram agitadas durante $1 \mathrm{~h}$ para permitir a partição dos corantes entre a fase aquosa e a orgânica e deixada em repouso durante $24 \mathrm{~h}$ para separação das duas fases. As concentrações dos corantes em PBS antes e após a partição foram medidas espectroscopicamente nos comprimentos de onda do máximo da banda de absorção de cada FS. As medidas foram realizadas cinco vezes para cada FS. O logaritmo do coeficiente de partição, log $\mathrm{P}$, foi calculado de acordo com a seguinte equação:

$$
\log P=\left[\frac{\left(A b s_{A}\right)}{\left(A b s_{D}\right)}-1\right] \times \frac{V_{\mathrm{H}_{2} \mathrm{O}}}{V_{\mathrm{OCT}}}
$$

Onde: 
$\log P=\operatorname{logaritmo}$ do coeficiente de partição

Abs $_{A}=$ absorção ótica da solução antes da partição

Abs ${ }_{D}=$ absorção ótica da solução depois da partição

$\mathrm{V}_{\mathrm{PBS}}=$ volume de PBS

$\mathrm{V}_{\mathrm{OCT}}=$ volume de octanol

\subsection{Métodos utilizados no estudo teórico}

Inicialmente, as geometrias dos compostos estudados (AM, ATO, ER, EY, FL e RB) foram otimizadas. Para garantir que a geometria obtida se trata de um mínimo na superfície potencial, foram calculadas as freqüências, ou seja, no caso de obtenção de freqüências imaginárias, nova otimização de geometria foi realizada. Todos esses cálculos foram realizados em termos da implementação de Kohn-Sham da Teoria do DFT, com o funcional B3LYP ${ }^{104-106}$, a base DGDZVP e o solvente (água) simulado com o método contínuo Integral Equation Formalism of Polarizable Continuum Model $(\text { IEFPCM })^{107-109}$, conforme implementados no programa Gaussian $03^{110}$, uma vez que essa metodologia já se mostrou muito eficiente em estudos com corantes semelhantes ${ }^{111,112}$.

Uma vez obtidas as estruturas de menor energia, foram calculadas as seguintes propriedades:

- energia total e entalpia de formação: para comparação da estabilidade relativa dos corantes;

- energia e representação gráfica do HOMO (último orbital molecular ocupado) e do LUMO (primeiro orbital molecular desocupado). As energias do HOMO e do 
LUMO fornecem indícios sobre a capacidade de uma molécula doar ou aceitar elétrons ${ }^{113}$

- momento de dipolo e cargas atômicas derivadas do potencial eletrostático (CHELPG): indicam como as moléculas podem interagir com o meio e/ou substrato eletrostaticamente. O método das cargas derivadas do potencial eletrostático é considerado melhor que o método de Mulliken para descrever interações intermoleculares ${ }^{114}$.

Todas essas propriedades foram calculadas utilizando a mesma metodologia que a utilizada para a otimização de geometria, ou seja, B3LYP/DGDZVP/IEFPCM. Além disso, foi calculado também o espectro de absorção utilizando a DFT dependente do tempo (TD-DFT), também no esquema B3LYP/DGDZVP/IEFPCM. Embora o método ZINDO tenha se mostrado o melhor método para descrever o $\mathrm{AM}^{111,112}$, não foi possível utilizá-lo neste trabalho uma vez que, no programa Gaussian 03, ele não é parametrizado para o átomo de lodo (presente tanto em ER quanto em RB) e para o Bromo (presente em EY). Entretanto, como demonstrado nas referências 111 e 112, TD-DFT também apresenta bons resultados que podem ser utilizados para comparações entre os corantes estudados na escolha de um bom FS. Foram calculadas, ainda, com o programa HyperChem ${ }^{115}$ as seguintes propriedades: área e volume para cada molécula estudada.

\subsection{Cálculo da média amostral e do desvio padrão}

Nas análises que fizeram uso da média amostral e do desvio padrão os cálculos foram realizados segundo as equações 6 e $7^{116}$ : 


$$
\begin{gathered}
\overline{X i}=\frac{\sum_{i=1}^{n} X_{i}}{n} \\
S_{j}=\sqrt{\frac{\sum_{i=1}^{n}\left(X_{i}-\bar{X}_{j}\right)^{2}}{n-1}}
\end{gathered}
$$

Onde:

$$
\begin{aligned}
& \overline{X i}=\text { média amostral } \\
& X_{i}=\text { i-ésima observação } \\
& \mathrm{n}=\text { número total de observações } \\
& S_{j}=\text { estimativa do desvio padrão }
\end{aligned}
$$




\section{RESULTADOS E DISCUSSÕES}

\subsection{Experimentos de citoxicidade}

Foram realizados experimentos de citotoxicidade com a linhagem HEp-2 em que as células foram irradiadas com duas doses diferentes de luz para os corantes fenotiazínicos e uma dose de luz para os corantes xantenos com diferentes tempos de incubação dos fotossensibilizadores. Foram também realizados ensaios citotóxicos na ausência de irradiação a fim de se verificar a toxicidade intrínseca dos fotossensibilizadores nas células, ou seja, a citotoxicidade no escuro. Os valores de $\mathrm{IC}_{50}$ obtidos estão apresentados na Tabela 1 (para os corantes fenotiazínicos) e na Tabela 2 (para os corantes xantenos). Deve-se mencionar que esse parâmetro é inversamente proporcional à citotoxicidade, ou seja, quanto maior o valor de $\mathrm{IC}_{50}$, menor é a citotoxicidade.

A partir dos valores da Tabela 1 observa-se que o tempo de incubação do FS nas células afetou sua citotoxicidade, pois seu aumento causou uma diminuição no valor de $\mathrm{IC}_{50}$, isso significa que quanto maior o tempo de incubação, menor a concentração de FS necessária para matar as células, tanto na ausência (escuro) quanto na presença de luz (claro). Comparando-se $2 \mathrm{~h}$ com 6h de incubação para o AM e para o ATO, no escuro, houve uma diminuição do $\mathrm{IC}_{50}$ de $77 \%$ para o $\mathrm{AM}$ e $55 \%$ para o ATO, sendo estes resultados coerentes uma vez que existem controles cinéticos para a incorporação do corante nas células ${ }^{95}$. No entanto, apenas $6 \%$ de decréscimo no valor de $\mathrm{IC}_{50}$ ocorre quando o tempo de incubação passa de 2 para $4 \mathrm{~h}$ de incubação 
para o AM. Já para o ATO não há mais diminuição do $I_{50}$ no escuro com tempos maiores que $4 \mathrm{~h}$, indicando que esse tempo de incubação é ideal para esse corante.

Através da Tabela 1 é possível observar também que o ATO é mais citotóxico do que o $\mathrm{AM}$, tanto na presença quanto na ausência de irradiação, exceto na dose de 36 $\mathrm{J} / \mathrm{cm}^{2}$ e $6 \mathrm{~h}$ de incubação, em que se obteve os mesmos valores de $\mathrm{IC}_{50}$ para os dois corantes. Essa observação sugere claramente a importância da dosimetria, ou seja, da otimização dos parâmetros de PDT para se obter a máxima eficiência.

Tabela 1: Citotoxicidade no claro e no escuro dos corantes fenotiazinicos na linhagem celular HEp-2 em função do tempo de irradiação e da dose de luz. A intensidade do LED utilizado nas irradiações foi de $11 \mathrm{~mW} \mathrm{~cm}^{-2}$, com $\mathrm{n}=7$.

\begin{tabular}{|c|c|c|c|c|}
\hline Corante & $\begin{array}{l}\text { Dose de luz } \\
\qquad\left(\mathrm{J} / \mathrm{cm}^{2}\right)\end{array}$ & $\begin{array}{c}\text { Tempo de } \\
\text { incubação } \\
\text { (h) }\end{array}$ & $\begin{array}{c}\mathbf{I C}_{50} \text { claro } \\
(\mu \mathrm{g} / \mathrm{mL})\end{array}$ & $\begin{array}{c}\text { IC }_{50} \text { escuro } \\
(\mu \mathrm{g} / \mathrm{mL})\end{array}$ \\
\hline \multirow{6}{*}{ Azul de Metileno } & \multirow{3}{*}{18} & 2 & $16 \pm 2$ & $18 \pm 3$ \\
\hline & & 4 & $10 \pm 2$ & $17 \pm 2$ \\
\hline & & 6 & $1.4 \pm 0.1$ & $4.2 \pm 0.1$ \\
\hline & \multirow{3}{*}{36} & 2 & $9.0 \pm 0.1$ & $18 \pm 3$ \\
\hline & & 4 & $0.75 \pm 0.05$ & $17 \pm 2$ \\
\hline & & 6 & $0.04 \pm 0.01$ & $4.2 \pm 0.1$ \\
\hline \multirow{6}{*}{ Azul de Toluidina 0} & \multirow{3}{*}{18} & 2 & $7 \pm 1$ & $9 \pm 1$ \\
\hline & & 4 & $0.70 \pm 0.06$ & $4.0 \pm 0.9$ \\
\hline & & 6 & $0.12 \pm 0.01$ & $4.0 \pm 0.9$ \\
\hline & \multirow{3}{*}{36} & 2 & $6.0 \pm 0.2$ & $9 \pm 1$ \\
\hline & & 4 & $0.15 \pm 0.09$ & $4.0 \pm 0.9$ \\
\hline & & 6 & $0.03 \pm 0.01$ & $4.0 \pm 0.3$ \\
\hline
\end{tabular}


No claro observa-se que aumentando o tempo de 2 para 4 e 6 h, ocorre um decréscimo no valor de $\mathrm{IC}_{50}$, indicando que o tempo de incubação maior facilita a sensibilização das células e sua inativação na presença de luz. Por outro lado, pode-se observar a enorme potencialização da citotoxicidade causada pela luz, que é maior quanto mais elevada for a dose de luz aplicada nas células na presença do fotossensibilizador.

É possível observar através da Tabela 2, que para os corantes xantenos o tempo de incubação também afetou sua citotoxicidade, pois quanto maior o tempo de incubação menor é o valor de $\mathrm{IC}_{50}$, no escuro, provavelmente devido a maior incorporação do FS nas células, sendo este efeito maior para EY e FL que tiveram um aumento de 2,6 e 2,7 em sua citotoxicidade, no escuro, respectivamente.

Tabela 2: Citotoxicidade no claro e no escuro dos corantes xantenos na linhagem celular HEp-2 em função do tempo de incubação e da dose de luz de $18 \mathrm{~J} / \mathrm{cm}^{2}$. A intensidade do LED utilizado nas irradiações foi de $19 \mathrm{~mW} \cdot \mathrm{cm}^{-2}$, com $\mathrm{n}=7$.

\begin{tabular}{|c|c|c|c|}
\hline Corante & $\begin{array}{c}\text { Tempo de incubação } \\
(\mathrm{h})\end{array}$ & $\begin{array}{c}\mathbf{I C}_{50} \text { claro } \\
(\mu \mathrm{g} / \mathrm{mL})\end{array}$ & $\begin{array}{c}\mathbf{I C}_{50} \text { escuro } \\
(\mu \mathrm{g} / \mathrm{mL})\end{array}$ \\
\hline \multirow{2}{*}{ Rose Bengal } & 4 & $67 \pm 2$ & $81 \pm 2$ \\
\cline { 2 - 4 } & 6 & $11 \pm 1$ & $58 \pm 2$ \\
\hline \multirow{2}{*}{ Eritrosina B } & 4 & $124 \pm 8$ & $186 \pm 3$ \\
\cline { 2 - 4 } & 6 & $74 \pm 3$ & $125 \pm 10$ \\
\hline Eosina Y & 4 & $213 \pm 13$ & $357 \pm 9$ \\
\cline { 2 - 4 } & 6 & $104 \pm 7$ & $135 \pm 8$ \\
\hline Fluoresceína & 4 & $1644 \pm 150$ & $630 \pm 60$ \\
\cline { 2 - 4 } & 6 & $370 \pm 35$ & 200 \\
\hline
\end{tabular}


A ação destes fotossensibilizadores também foi potencializada com a irradiação, principalmente para o RB que teve uma diminuição de $84 \%$ no valor de $I_{50}$, no claro, de 4 para $6 \mathrm{~h}$ de incubação. Sendo assim, dentre os xantenos estudados, RB foi o mais citotóxico na linhagem de células tumorais HEp-2. Observou-se também que os corantes fenotiazínicos são mais citotóxicos nesta linhagem do que os xantenos, sendo que o ATO foi o mais citotóxico dentre todos os corantes estudados.

\subsection{Experimento de fotoxidação do acido úrico}

O AU é um eficiente captador de oxigênio singlete que pode ser usado como dosímetro químico para a determinação quantitativa da ação fotodinâmica de fotossensibilizadores através de um método proposto por Fischer et.al. ${ }^{81}$

A figura 5 apresenta o espectro de absorção ótica do AU. Observa-se que o AU possui duas bandas de absorção máxima na região do espectro UV/Visível em 235 e 292 nm e não possui absorbância nos comprimentos de onda de irradiação (532 verde e $628 \mathrm{~nm}$ vermelho), garantindo que a luz só vai ser absorvida pelos fotossensibilizadores nos experimentos de determinação da atividade fotodinâmica. Estudos realizados pelo grupo mostraram que a banda de absorção em $292 \mathrm{~nm}$ é mais facilmente afetada pelo efeito fotodinâmico durante a reação de fotoxidação, por isso o decréscimo da absorção foi verificado nesse comprimento de onda e não em $235 \mathrm{~nm}^{76}$. 


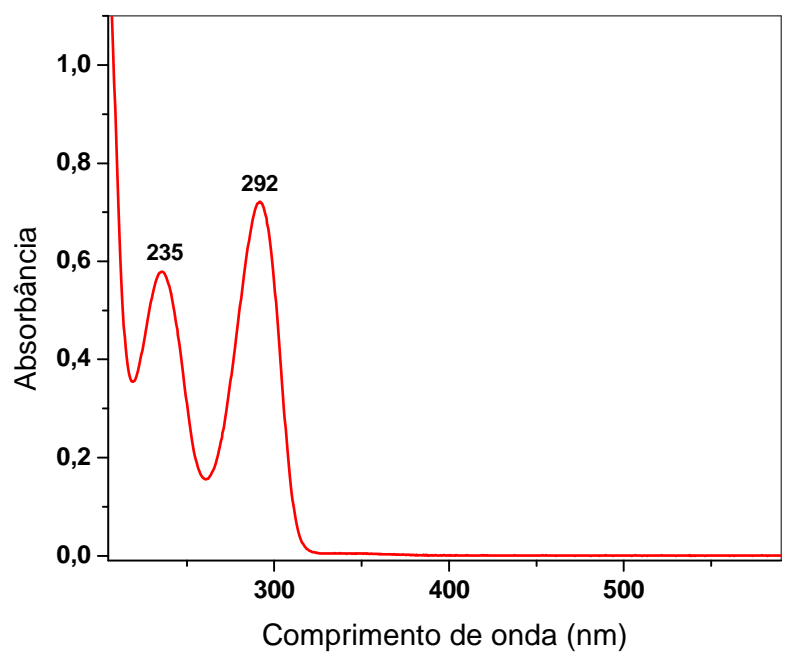

Figura 5. Espectro de absorção ótica de uma solução de ácido úrico $(10 \mu \mathrm{g} / \mathrm{mL})$ em PBS, na ausência de corante.

Foram irradiadas amostras contendo FS $(5 \mu \mathrm{g} / \mathrm{mL})$ e AU $(10 \mu \mathrm{g} / \mathrm{mL})$ com LED de comprimento de onda adequado por 360 s. O procedimento padrão estipulou um limite de tempo de irradiação na faixa de 200 a 500s, a fim de garantir uma correlação linear entre a variação da absorbância do $A U$ e a concentração do FS, da mesma forma a fluência do laser é considerada linear na faixa de $70-190 \mathrm{~W} / \mathrm{m}^{2}{ }^{81}$. Os espectros de absorção do AU na presença dos diversos fotossensibilizadores foram obtidos e estão apresentados na figura 6 . 

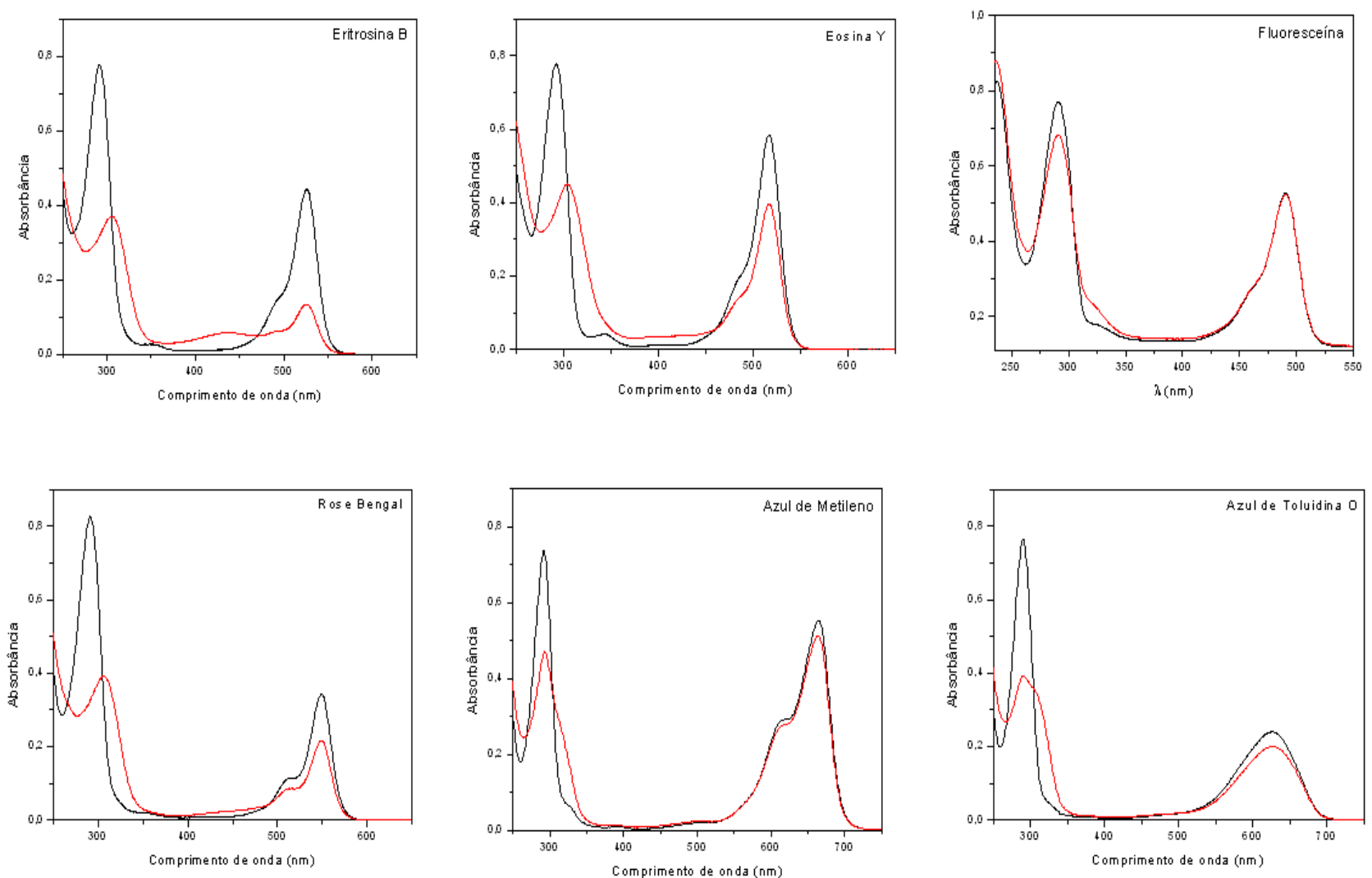

Figura 6: Espectros de absorção ótica antes e depois de irradiação com LED de misturas contendo ácido úrico $(10 \mu \mathrm{g} / \mathrm{mL})$ e corante $(5 \mu \mathrm{g} / \mathrm{mL})$, em PBS. Os espectros de absorção ótica evidenciam a diminuição da banda em $292 \mathrm{~nm}$ devido a fotoxidação do ácido úrico. A linha vermelha ( - ) indica o espectro obtido após o tempo de irradiação e a linha preta ( - ) indica o espectro obtido antes da irradiação.

É possível observar que além da molécula de AU, o próprio FS também sofreu dano devido ao efeito fotodinâmico. Este fenômeno é conhecido como fotodegradação e tem sido objeto de vários estudos por se tratar de uma característica diretamente relacionada com a dose terapêutica do $\mathrm{FS}^{76}$. Além disso, pode-se também observar que após a irradiação com laser, ocorre o decaimento da banda de absorção característica do AU em 292 nm como resultado de sua decomposição pelo oxigênio singlete formado pelos fotossensibilizadores excitados. Os valores da atividade fotodinâmica (AF) foram determinados pela equação $2^{81}$. 
Tabela 3: Valores de atividade fotodinâmica obtidos para os corantes xantenos e fenotiazínicos, sendo que os valores apresentados são as médias dos valores obtidos em quatro experimentos.

\begin{tabular}{|c|c|}
\hline Corante & $\begin{array}{c}\text { Atividade Fotodinâmica } \\
\left(\mathrm{m}^{2} / \mathrm{J}\right)\end{array}$ \\
\hline Rose Bengal & $6.0 \pm 0.3$ \\
\hline Eritrosina B & $5.6 \pm 0.5$ \\
\hline Azul de Toluidina O & $4.6 \pm 0.2$ \\
\hline Eosina Y & $4.2 \pm 0.6$ \\
\hline Azul de Metileno & $2.6 \pm 0.4$ \\
\hline Fluoresceína & $0.4 \pm 0.1$ \\
\hline
\end{tabular}

O RB foi o FS mais eficiente em causar a fotoxidação do AU, dentre todos os corantes, além de ser o mais eficiente dentre os xantenos e o ATO dentre os fenotiazínicos. Portanto os resultados obtidos no experimento de fotoxidação de AU estão de acordo com os resultados obtidos nos experimentos de citotoxicidade, onde RB e ATO possuem os menores valores de $I_{50}$ quando comparados com os demais corantes estudados da mesma família. Esta relação é possível de se verificar, pois o oxigênio singlete é considerado como sendo o principal agente responsável pelos danos causados nas células tumorais ${ }^{3,22,23,26}$ e fotossensibilizadores que ao serem irradiados produzam maiores quantidades de oxigênio singlete possuirão maiores efeitos citotóxicos. Sendo assim, os resultados dos experimentos de fotoxidação do AU e de determinação do $\mathrm{IC}_{50}$ convergem para a seguinte ordem de eficiência fotodinâmica: Rose Bengal $>$ Eritrosina $\mathrm{B}>$ Eosina $\mathrm{Y}>$ Fluoresceína, para os corantes xantenos e Azul de Toluidina O > Azul de Metileno, para os corantes fenotiazínicos. 


\subsection{Interação dos fotossensibilizadores com BSA}

A técnica de supressão de fluorescência pode revelar a natureza da ligação entre o FS e BSA através da análise dos dados de fluorescência obtidos no experimento (figura 7). Como foi dito anteriormente, o processo de supressão de fluorescência pode ser estático ou dinâmico. A supressão estática se refere à formação de um novo complexo fluoróforo-FS, esta formação geralmente induz mudanças no espectro de absorção, oferecendo assim um método adicional para diferenciar o processo de supressão. A supressão dinâmica se refere à interação do supressor (neste caso o FS) com a molécula excitada do fluoróforo e o aumento da temperatura resulta em um aumento na velocidade de difusão molecular e na constante de supressão dinâmica (Ksv). Existem várias maneiras de se distinguir a supressão estática e a dinâmica, incluindo a determinação de valores de Kq, a comparação dos valores de Ksv em diferentes temperaturas e do espectro de absorção do BSA na presença e na ausência do fotossensibilizador ${ }^{63,75}$. 

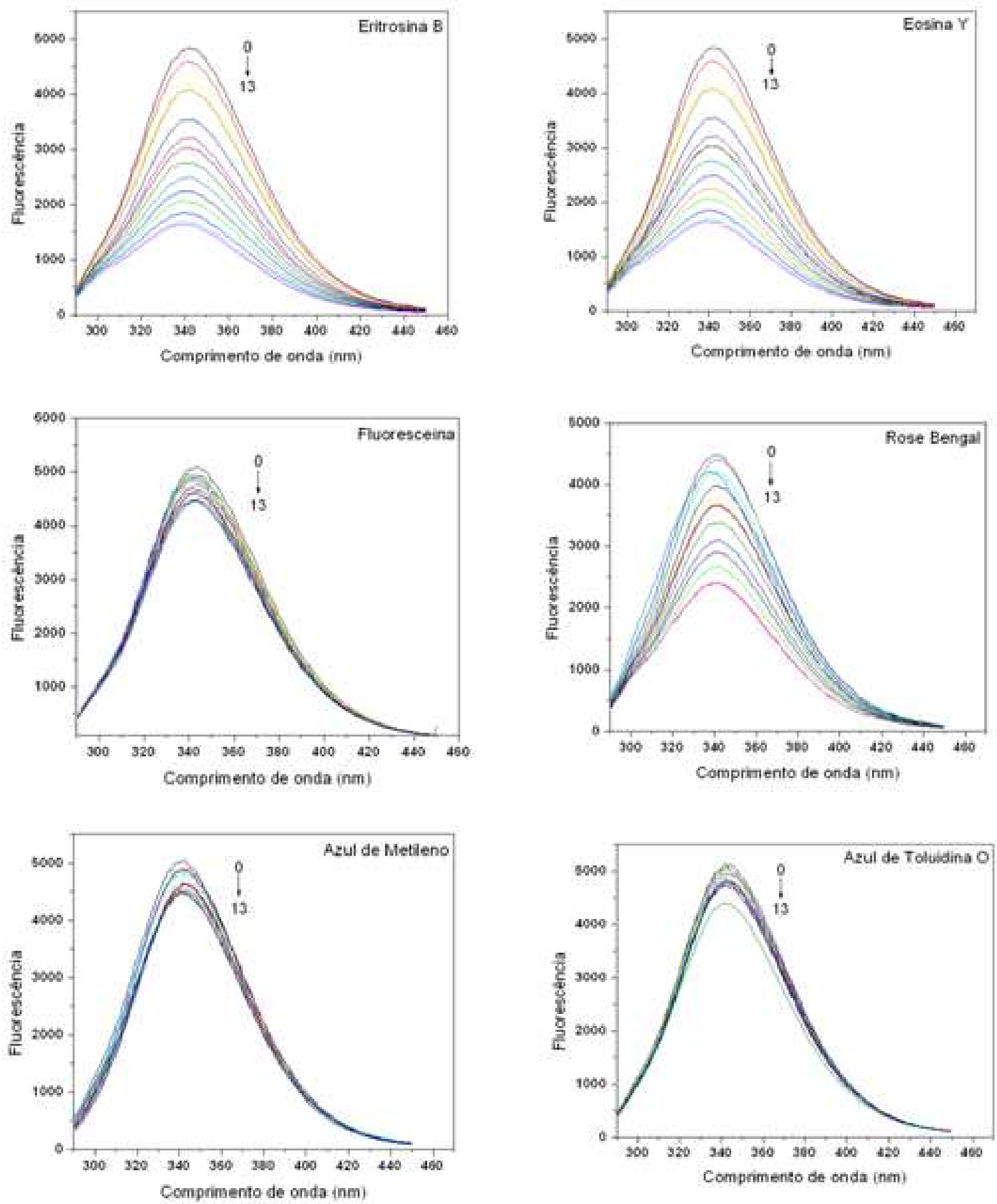

Figura 7. Espectro de absorção do BSA na ausência (0) e na presença de FS (1-13), a 25ㄷ. Concentração de FS: (1) $0.25 \mu \mathrm{M}$, (2) $0.5 \mu \mathrm{M}$, (3) $0.75 \mu \mathrm{M}$, (4) $1.00 \mu \mathrm{M}$, (5) $1.25 \mu \mathrm{M}$, (6) $1.50 \mu \mathrm{M}$, (7) 1.75 $\mu \mathrm{M}$, (8) $2.00 \mu \mathrm{M}$, (9) $2.25 \mu \mathrm{M}$, (10) $2.50 \mu \mathrm{M}$, (11) $2.75 \mu \mathrm{M}$, (12) $3.00 \mu \mathrm{M}$ e (13) $3.25 \mu \mathrm{M}$, respectivamente. Para todas as soluções, concentração de BSA: $2.00 \mu \mathrm{M}$. 
A figura 8 mostra a relação entre $F_{0} / F$ e [FS] (equação 3) para diferentes temperaturas, sendo que $F_{0}$ e $F$ são as intensidades de fluorescência do BSA em 340 nm, na ausência e na presença de FS, respectivamente e [FS] é concentração do fotossensibilizador.
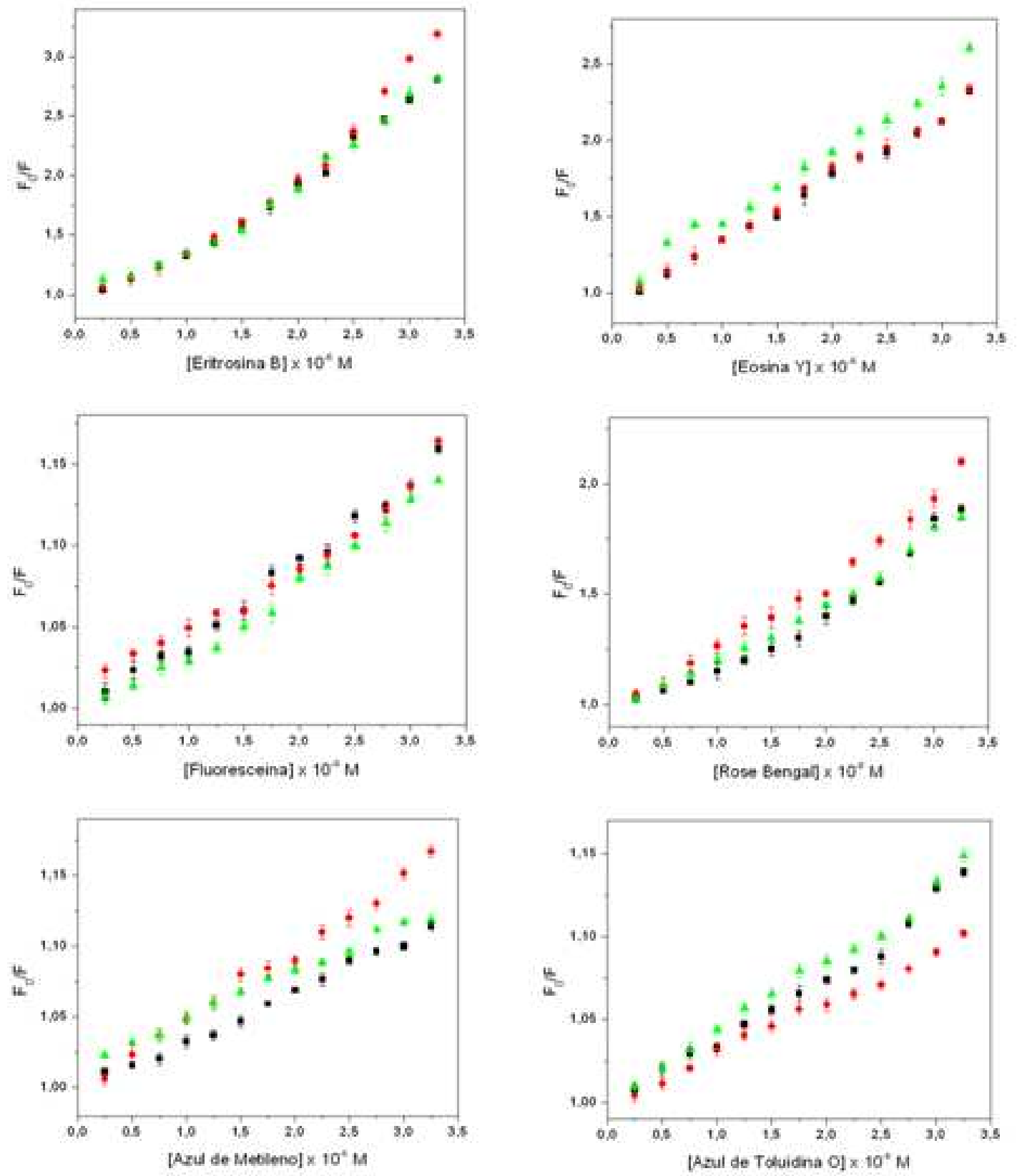

Figura 8. Gráfico de $F_{0} / F$ em função de [FS], onde: $20^{\circ}, \bullet 25^{\circ}$ e $\triangle 35^{\circ}$. 
A partir dos parâmetros obtidos, a constante de supressão dinâmica de SternVolmer (Ksv) e a constante de velocidade de supressão bimolecular (kq) foram calculadas e estão apresentados na Tabela 4.

Tabela 4. Valores de Ksv e Kq para a reação de BSA com cada um dos corantes em diferentes temperaturas, sendo $n=3$.

\begin{tabular}{|c|c|c|c|}
\hline Corante & $\begin{array}{c}\text { Temp. } \\
\left({ }^{\circ} \mathrm{C}\right)\end{array}$ & $\begin{array}{c}\text { Ksv } \\
\left(10^{5} \mathrm{M}^{-1}\right)\end{array}$ & $\begin{array}{c}\mathbf{K q} \\
\left(10^{13} \mathrm{M}^{-1} \mathrm{~s}^{-1}\right)\end{array}$ \\
\hline \multirow{3}{*}{ Eritrosina B } & 20 & $6.6 \pm 0.1$ & $6.6 \pm 0.1$ \\
\hline & 25 & $6.3 \pm 0.1$ & $6.3 \pm 0.1$ \\
\hline & 35 & $6.0 \pm 0.1$ & $6.0 \pm 0.1$ \\
\hline \multirow{3}{*}{ Eosina $Y$} & 20 & $4.1 \pm 0.1$ & $4.1 \pm 0.1$ \\
\hline & 25 & $4.3 \pm 0.2$ & $4.3 \pm 0.2$ \\
\hline & 35 & $4.6 \pm 0.1$ & $4.6 \pm 0.1$ \\
\hline \multirow{3}{*}{ Rose Bengal } & 20 & $3.5 \pm 0.1$ & $3.5 \pm 0.1$ \\
\hline & 25 & $3.0 \pm 0.1$ & $3.0 \pm 0.1$ \\
\hline & 35 & $2.7 \pm 0.1$ & $2.7 \pm 0.1$ \\
\hline \multirow{3}{*}{ Fluoresceína } & 20 & $0.5 \pm 0.1$ & $0.5 \pm 0.1$ \\
\hline & 25 & $0.5 \pm 0.1$ & $0.5 \pm 0.1$ \\
\hline & 35 & $0.4 \pm 0.1$ & $0.4 \pm 0.1$ \\
\hline \multirow{3}{*}{ Azul de Toluidina 0} & 20 & $0.4 \pm 0.1$ & $0.4 \pm 0.1$ \\
\hline & 25 & $0.4 \pm 0.1$ & $0.4 \pm 0.1$ \\
\hline & 35 & $0.3 \pm 0.1$ & $0.3 \pm 0.1$ \\
\hline \multirow{3}{*}{ Azul de Metileno } & 20 & $0.4 \pm 0.1$ & $0.4 \pm 0.1$ \\
\hline & 25 & $0.3 \pm 0.1$ & $0.3 \pm 0.1$ \\
\hline & 35 & $0.3 \pm 0.1$ & $0.3 \pm 0.1$ \\
\hline
\end{tabular}


Através da Tabela 4, observa-se que os valores da constante de supressão dinâmica de Stern-Volmer (Ksv) não aumentaram com o aumento da temperatura, permanecendo até constantes para FL e ATO em 20 e $25^{\circ} \mathrm{C}$ e para $\mathrm{AM}$ em 25 e $35^{\circ} \mathrm{C}$, constituindo-se em uma evidência para o processo de supressão estática e embora os valores de Ksv aumentem com o aumento da temperatura para a EY, a reação de ligação entre BSA e EY é uma supressão estática. Isso foi comprovado por Gao et.al. ${ }^{63}$ em pH 2.6 e 9.23 mostrando que o aumento na temperatura não provoca aumento em Ksv para EY. Verificou-se também que os valores de Kq e Ksv para o AM e ATO, são os menores quando comparados aos demais corantes, enquanto que a ER possui os maiores valores, além disso pode-se observar que a FL possui valores das constantes semelhantes aos dos fenotiazínicos estudados.

De acordo com a literatura, a constante de velocidade de colisão de difusão máxima obtida para vários supressores com o BSA é de $2.0 \times 10^{10} \mathrm{M}^{-1} \mathrm{~s}^{-1}$, se $\mathrm{Kq}$ for maior que este valor o processo de supressão é estático ${ }^{63,75,117}$. Através da Tabela 4 pode-se observar que os valores de $\mathrm{Kq}$ calculados neste experimento são maiores do que $2.0 \times 10^{10} \mathrm{M}^{-1} \mathrm{~s}^{-1}$, indicando assim, que a supressão de fluorescência do BSA na presença dos fotossensibilizadores é um processo de supressão estática.

No processo de supressão estática, a formação do complexo fluoróforo-FS influencia o espectro de absorção do BSA ou do FS, sendo assim, medidas de absorção constitui-se em um método simples e efetivo de se observar a mudança de estrutura devida a formação do complexo. A figura 9 mostra os espectros de absorção do BSA-FS, BSA e FS a $25^{\circ} \mathrm{C}$. 

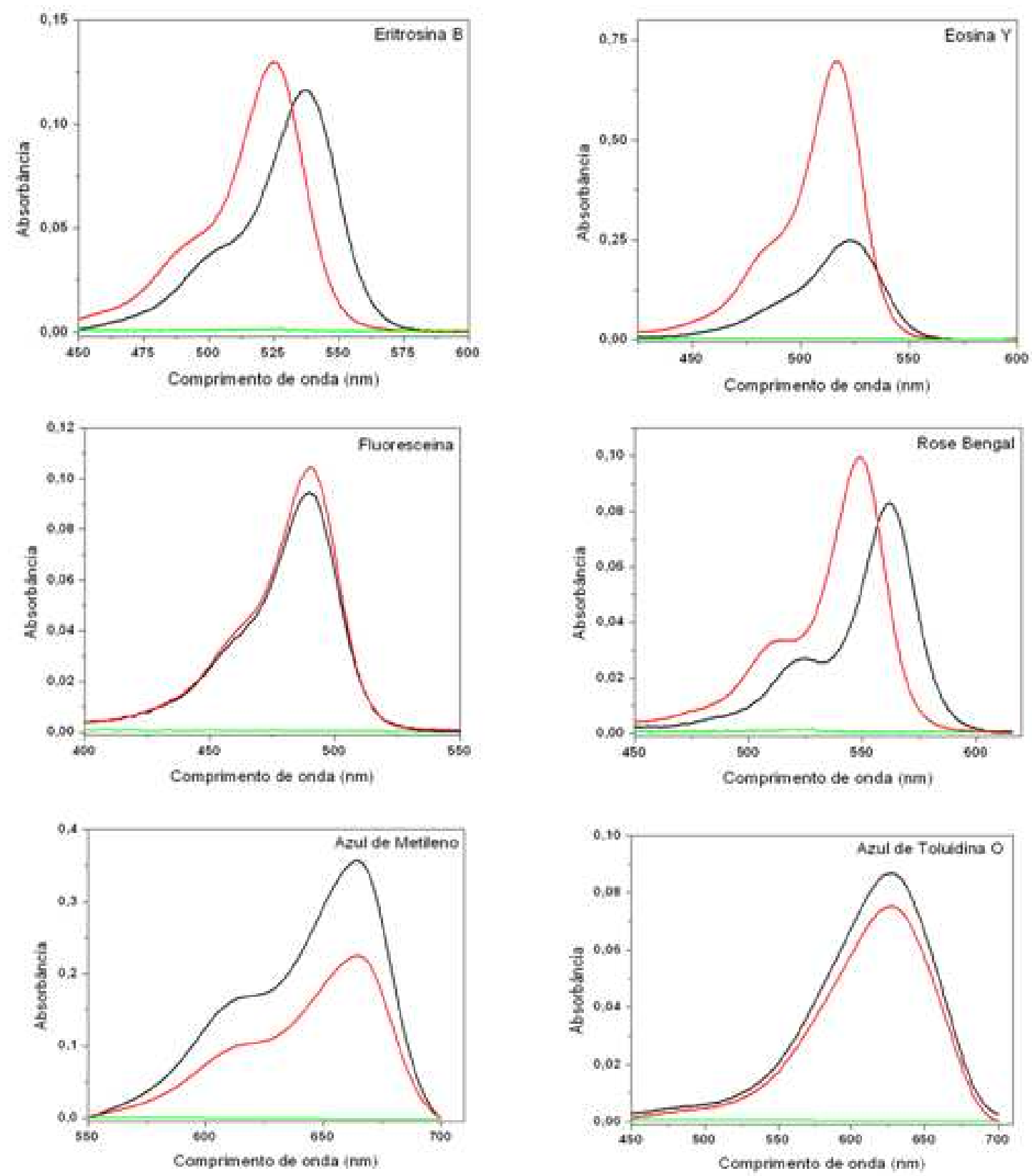

Figura 9. Espectro de absorção de BSA, FS, BSA-FS a $25^{\circ} \mathrm{C}$, onde (-) BSA-FS, (-) BSA e (-) FS. As concentrações de BSA e FS são 2.00 e $2.00 \mu \mathrm{M}$, respectivamente.

Pode-se observar facilmente que a adição do FS a uma solução contendo BSA induz a uma mudança no espectro de absorção do FS, esta mudança pode ser atribuída a mudança na estrutura do FS, indicando a formação de um complexo BSA- 
FS. Sendo assim, baseado na discussão acima, pode-se concluir que o processo de supressão para a reação de ligação do BSA com os corantes estudados é estático ao invés de dinâmico.

A constante de ligação $\left(\mathrm{K}_{\mathrm{A}}\right)$ e o número de sítios de ligação $(\mathrm{n})$ foram calculados através da equação 4 usando os dados obtidos no experimento. O gráfico de $\log \left(\left(\mathrm{F}_{0^{-}}\right.\right.$ $\mathrm{F}) / \mathrm{F})$ em função do log $\left([\mathrm{FS} \mathrm{t}]-\mathrm{n}\left[\mathrm{BSA}_{\mathrm{t}}\right]\left(\mathrm{F}_{0}-\mathrm{F}\right) / \mathrm{F}_{0}\right)$, para cada corante está representado na figura 10, sendo uma reta com inclinação igual a n. Quando o número do sítios de ligação e o coeficiente linear ( $\mathrm{n} \log \mathrm{K}_{\mathrm{A}}$ ) são conhecidos, os valores de $\mathrm{K}_{\mathrm{A}}$ para cada corante podem ser facilmente calculados ${ }^{63,75}$.

Através da Tabela 5 , pode-se observar, que $\mathrm{K}_{\mathrm{A}}$ e $\mathrm{n}$ para as reações dos fotossensibilizadores com BSA possui valores diferentes para cada temperatura. Com o aumento da temperatura, ocorre uma diminuição nos valores de $\mathrm{K}_{\mathrm{A}}$, pois o aumento da temperatura diminui a estabilidade do complexo BSA-FS formado, sendo característico da supressão estática. Verificou-se também que $E Y$ possui os maiores valores de $\mathrm{K}_{\mathrm{A}}$, além disso, FL, AM e ATO também possuem valores semelhantes desta constante, sendo que também possuem valores semelhantes de Ksv e Kq. As diferenças nos valores das constantes de cada FS, deve-se as diferenças nas estruturas de cada um, pois a interação do FS com BSA, depende da estrutura de ambos. 

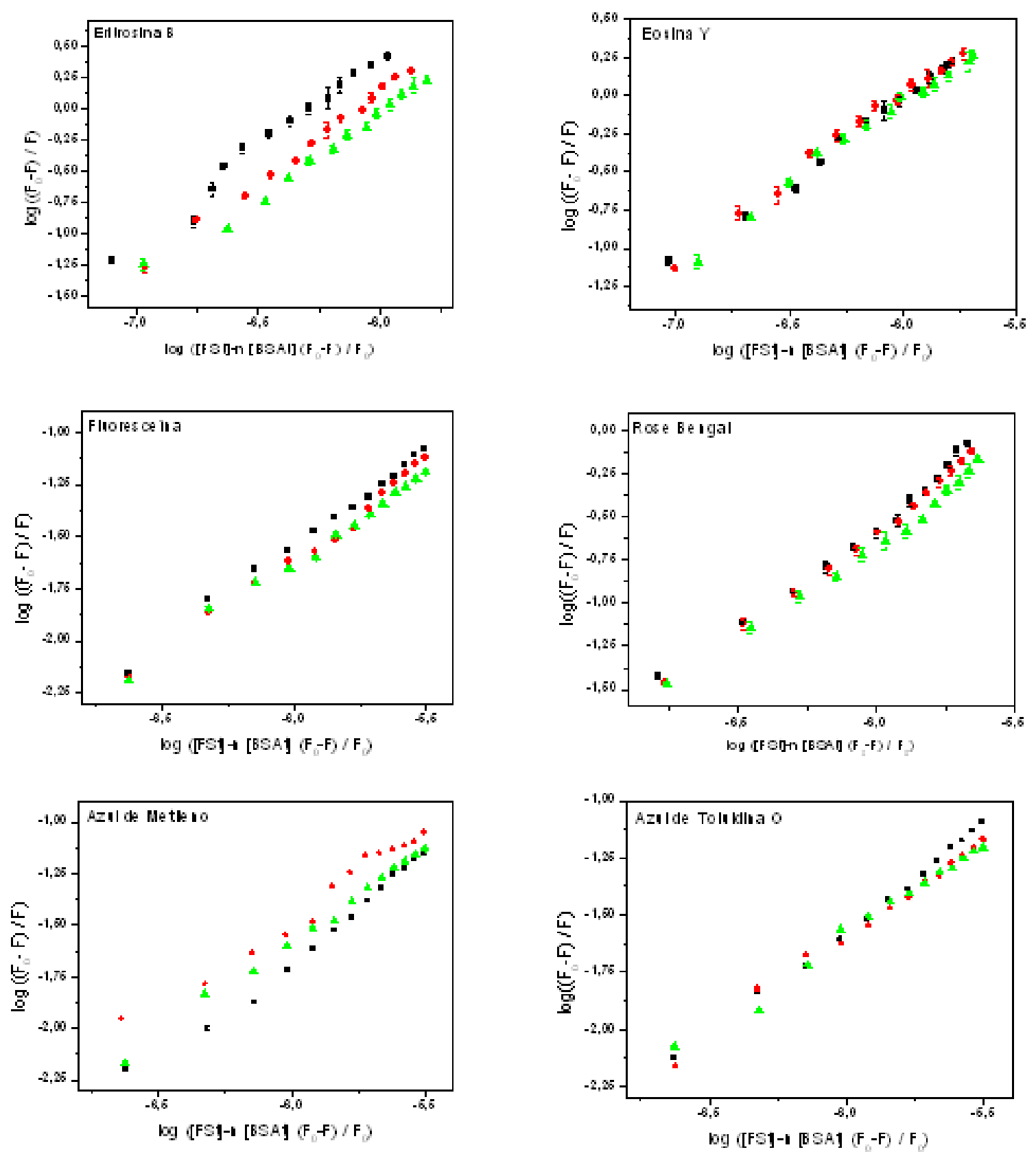

Figura 10. Gráfico de $\log \left(\left(\mathrm{F}_{0}-\mathrm{F}\right) / \mathrm{F}\right)$ versus log $\left(\left[\mathrm{FS}_{\mathrm{t}}\right]-\mathrm{n}\left[\mathrm{BSA}_{\mathrm{t}}\right]\left(\mathrm{F}_{0}-\mathrm{F}\right) / \mathrm{F}_{0}\right)$ para a reação dos corantes com BSA, onde: $20^{\circ} \mathrm{C}, 25^{\circ} \mathrm{C}$ e $\triangle 35^{\circ} \mathrm{C}$.

A Tabela 5 apresenta os valores da constante de ligação do BSA com FS e os valores dos números de sítios de ligação. 
Tabela 5. Valores das constantes de ligação e dos números de sítios de ligação para os corantes com BSA nos diferentes valores de temperatura.

\begin{tabular}{|c|c|c|c|}
\hline Corante & $\begin{array}{c}\text { Temp. } \\
\left({ }^{\circ} \mathrm{C}\right)\end{array}$ & $\begin{array}{c}\mathbf{K}_{\mathbf{A}} \\
\left(10^{5} \mathrm{M}^{-1}\right)\end{array}$ & $\mathbf{n}$ \\
\hline \multirow{3}{*}{ Eosina $Y$} & 20 & $22 \pm 2$ & $1.0 \pm 0.1$ \\
\hline & 25 & $21 \pm 2$ & $1.0 \pm 0.1$ \\
\hline & 35 & $20 \pm 2$ & $0.9 \pm 0.1$ \\
\hline \multirow{3}{*}{ Eritrosina B } & 20 & $19 \pm 2$ & $1.5 \pm 0.1$ \\
\hline & 25 & $12 \pm 2$ & $1.4 \pm 0.1$ \\
\hline & 35 & $9 \pm 1$ & $1.3 \pm 0.1$ \\
\hline \multirow{3}{*}{ Rose Bengal } & 20 & $3.5 \pm 0.3$ & $1.2 \pm 0.1$ \\
\hline & 25 & $3.3 \pm 0.2$ & $1.2 \pm 0.1$ \\
\hline & 35 & $2.6 \pm 0.2$ & $1.1 \pm 0.1$ \\
\hline \multirow{3}{*}{ Azul de Metileno } & 20 & $0.2 \pm 0.1$ & $1.0 \pm 0.1$ \\
\hline & 25 & $0.2 \pm 0.1$ & $1.0 \pm 0.1$ \\
\hline & 35 & $0.2 \pm 0.1$ & $0.9 \pm 0.1$ \\
\hline \multirow{3}{*}{ Fluoresceína } & 20 & $0.2 \pm 0.1$ & $0.9 \pm 0.1$ \\
\hline & 25 & $0.2 \pm 0.1$ & $0.9 \pm 0.1$ \\
\hline & 35 & $0.1 \pm 0.1$ & $0.9 \pm 0.1$ \\
\hline \multirow{3}{*}{ Azul de Toluidina 0} & 20 & $0.2 \pm 0.1$ & $0.9 \pm 0.1$ \\
\hline & 25 & $0.1 \pm 0.1$ & $0.8 \pm 0.1$ \\
\hline & 35 & $0.1 \pm 0.1$ & $0.8 \pm 0.1$ \\
\hline
\end{tabular}

Pode-se observar na Tabela 5, que para valores elevados de $\mathrm{K}_{\mathrm{A}} \mathrm{o}$ erro experimental obtido foi aproximadamente $10 \%$, mas para valores baixos o erro obtido foi muito elevado, dificultando uma análise mais aprofundada. Além disso, pode-se observar que o número de sítios é aproximadamente 1 para todos os corantes 
estudados em todas as temperaturas. O aumento da temperatura não deveria provocar mudanças no número de sítios de ligação, pois não provoca grandes mudanças na conformação do BSA, a menos que o aumento seja excessivo, de modo que provocasse uma mudança na conformação que causasse um impedimento a exposição dos aminoácidos, protegendo-os da ligação com os fotossensibilizadores, o que não foi o caso.

É muito importante conhecer a afinidade dos fotossensibilizadores pela albumina, sendo esta ligação importante especialmente para aqueles compostos pouco solúveis no plasma. Por outro lado, se a ligação entre o FS e a albumina for muito forte, a ação do FS pode ser limitada, pois significa que uma menor concentração de FS estará disponível para a ação fisiológica ${ }^{70}$. Os corantes fenotiazínicos possuem menor afinidade por BSA do que os xantenos (com exceção da FL). Isso corrobora com o fato destes corantes serem mais utilizados clinicamente do que os xantenos, pois por não se ligarem tão fortemente a albumina não tem sua atividade biológica limitada, por essa razão.

\subsection{Determinação dos coeficientes de partição dos fotossensibilizadores}

No processo de planejamento e otimização de fármacos, é necessário conhecer seu comportamento nos vários compartimentos farmacológicos em que se encontrará, isto se relaciona ao comportamento de partição do composto entre a água, que está presente em praticamente todo meio biológico, e nos vários tipos de lipídeos encontrados, por exemplo, na membrana celular ou como parte da mistura complexa de proteínas do sangue, isto é, do balanço hidrofílico/lipofílico do fármaco. Uma medida 
simples, in vitro, deste comportamento é o logaritmo do coeficiente de partição do composto entre dois solventes, que normalmente são água e 1-octanol ${ }^{44}$. Os valores dos coeficientes de partição para os fotossensibilizadores empregados neste estudo foram obtidos e estão apresentados na Tabela 6.

Tabela 6 - Valores dos logaritmos dos coeficientes de partição para cada corante.

\begin{tabular}{|c|c|}
\hline Corante & Log P \\
\hline Rose Bengal & $0.66 \pm 0.01$ \\
\hline Azul de Metileno & $0.41 \pm 0.05$ \\
\hline Azul de Toluidina O & $0.23 \pm 0.02$ \\
\hline Eritrosina B & $-0.35 \pm 0.04$ \\
\hline Fluoresceína & $-0.65 \pm 0.07$ \\
\hline Eosina Y & $-1.00 \pm 0.02$ \\
\hline
\end{tabular}

Em termos quantitativos, o caráter hidrofílico está associado a pouca distribuição do FS no octanol, com Log $\mathrm{P}<0$ para estes compostos. O caráter lipofílico é atribuído aos compostos com $\log P>+1.5$, sendo que, as substâncias que possuem valores intermediários são consideradas anfifílicas. De um ponto de vista prático, fotosensibilizadores altamente lipofílicos podem não ser tão vantajosos, pois não são solúveis em meio aquoso, dificultando a administração ao paciente ${ }^{36}$.

O balanço hidrofílico/lipofílico do FS desempenha um papel muito importante na determinação da sua localização na célula, e consequentemente, o seu sítio de ação $0^{8,35,47}$. A localização do FS também depende da sua carga ${ }^{8,36}$, sendo que fotossensibilizadores lipofílicos e com carga positiva ou negativa menor que 2 podem 
difundir pela membrana plasmática e se relocalizar em outras membranas intracelulares e aqueles fotossensibilizadores hidrofílicos e com carga negativa maior que 2 tendem a ser muito polares para difundir através da membrana plasmática, tendo sua ação restrita à membrana plasmática ou então são incorporados por endocitose ${ }^{8}$. Além disso, fotossensibilizadores lipofílicos e com carga positiva tendem a se localizar na mitocôndria ${ }^{40,41}$, a ativação de fotossensibilizadores localizados na mitocôndria produz apoptose ${ }^{8,64}$, por isso que este é considerado um importante alvo celular na PDT.

Através da Tabela 6, pode-se observar que RB, AM e ATO são considerados como sendo anfifílicos $(0<\log P<1.5)$ e ER, EY e FL são hidrofílicos (Log $P<0)$. Notase que RB é o único composto anfifílico dentre os corantes xantenos, sendo também o mais hidrofóbico em comparação aos demais corantes estudados, enquanto que EY é o mais hidrofílico com Log $P=-1.0$. Verificou-se também que os fenotiazínico são anfifílicos, sendo que o ATO é menos hidrofóbico do que o AM, resultado coerente com a literatura $36,37,43,47$.

Já foi observado que os fenotiazínicos são mais citotóxicos do que os xantenos, o que corrobora com os valores de Log $\mathrm{P}$, pois também são mais hidrofóbicos, em comparação aos demais xantenos, com exceção do RB. Além disso, a combinação de carga positiva e moderada lipofilicidade os tornam capazes de difundir através da membrana plasmática e se localizar em organelas intracelulares, sendo que, estudos mostram que ATO e AM se localizam primeiramente nos lissosomos e depois se relocalizam no núcleo celular $33,38,40,41$. Outro fato interessante é que apesar do AM ser mais hidrofóbico do que o ATO, mostrou ser menos eficiente em causar a morte celular da linhagem estudada, este fato pode ser explicado em relação à atividade 
fotodinâmica $(A F)$, pois ATO possui valores bem maiores de $A F$ do que $A M(A F=4.6$ e $2.6 \mathrm{~m}^{2} / \mathrm{J}$, respectivamente), sendo portanto, mais eficiente na geração de ${ }^{1} \mathrm{O}_{2}$.

Nota-se também que $\mathrm{RB}$, apesar de ser um excelente gerador de ${ }^{1} \mathrm{O}_{2}(\mathrm{AF}=6$ $\mathrm{m}^{2} / \mathrm{J}$ ) e o composto mais hidrofóbico dentre os corantes estudados, não é o mais citotóxico, este fato pode ser explicado em termos de sua localização celular, pois estudos mostram que o primeiro efeito biológico do RB na PDT é através de modificações na membrana celular ${ }^{61,62}$, provavelmente, sua carga negativa (-2) promova a localização nesta membrana. Danos na membrana celular não implica necessariamente em morte celular, pois dependendo do tipo e da extensão do dano a célula pode se recuperar e sobreviver.

Os corantes ER, EY apesar de serem bons geradores de ${ }^{1} \mathrm{O}_{2}(\mathrm{AF}=5.6$ e 4.2 $\mathrm{m}^{2} / \mathrm{J}$, respectivamente) são os menos citotóxicos em celulas HEp-2, ou seja, possuem os maiores valores de $\mathrm{IC}_{50}$. Este fato é coerente com os valores de Log P obtidos, pois são hidrofílicos e possuem carga negativa (-2), tendendo, de acordo com a literatura, a se localizar na membrana plasmática ${ }^{55}$. Já a FL além de ser hidrofílico e com carga negativa, possui baixos valores de atividade fotodinâmica $\left(0.36 \mathrm{~m}^{2} / \mathrm{J}\right)$, explicando assim o fato de ser o menos eficiente dentre os corantes estudados.

\subsection{Estudo teórico dos fotossensibilizadores}

A Figura 11 apresenta as estruturas otimizadas e os eixos cartesianos para os seis corantes estudados. 


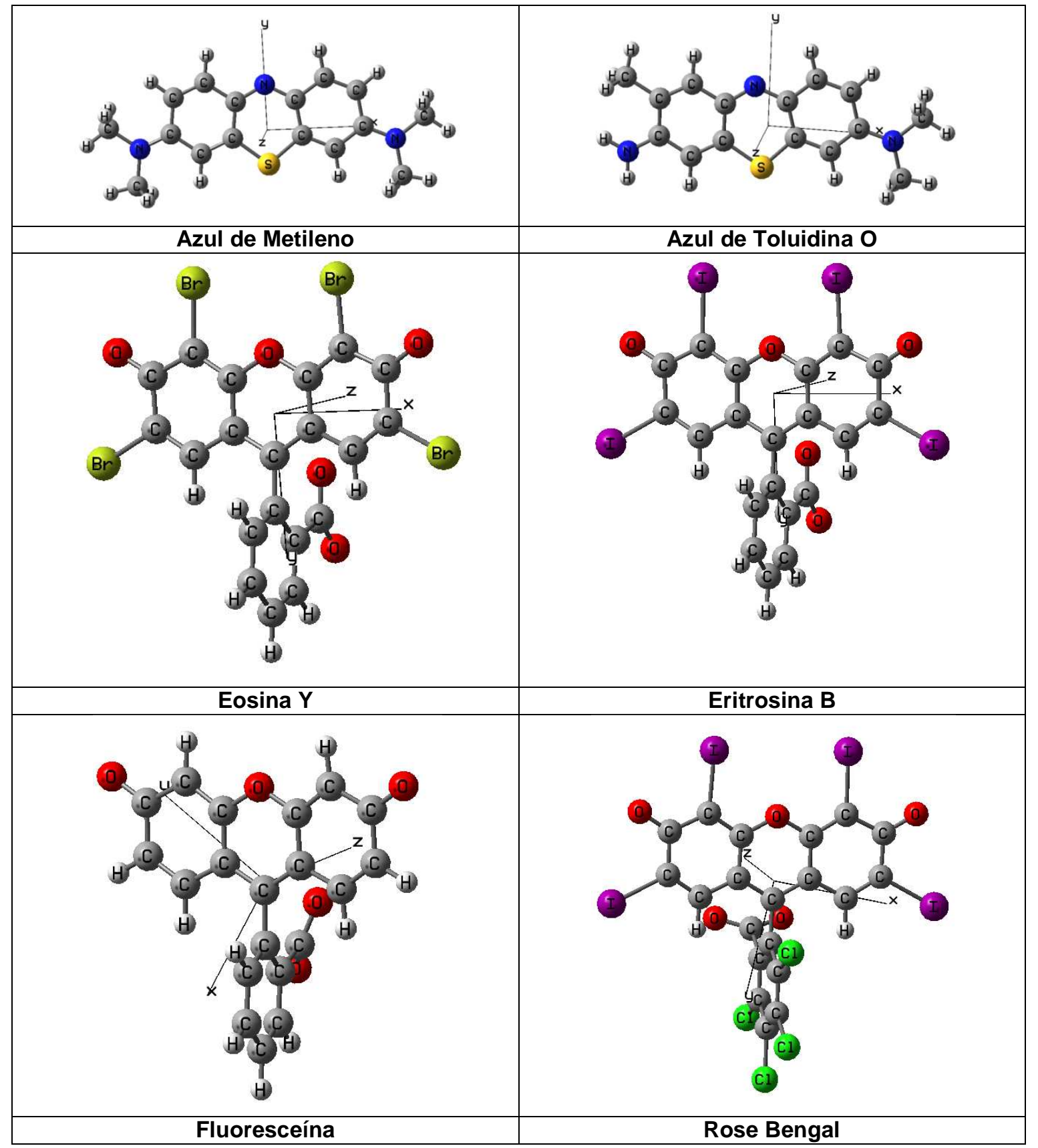

Figura 11. Estruturas otimizadas e os eixos cartesianos para as moléculas estudadas.

Os resultados teóricos mostraram que os corantes fenotiazínicos são moléculas essencialmente planares em contraste com os xantenos, cujo anel fenílico encontra-se 
em posição perpendicular ao plano da molécula. A Tabela 7 apresenta as propriedades calculadas para as seis moléculas estudadas, conforme descrito na metodologia.

Tabela 7. Propriedades obtidas por métodos teóricos para os corantes estudados.

\begin{tabular}{|c|c|c|c|c|c|c|}
\hline Propriedade & MB & TBO & FL & ER & EY & RB \\
\hline $\begin{array}{c}\text { ET } \\
\text { (u.a.) }\end{array}$ & -1182.8 & -1143.5 & -1144.7 & -28821.7 & -11437.0 & -30659.9 \\
\hline $\begin{array}{c}\Delta \mathrm{H}_{\mathrm{f}} \\
\text { (u.a.) }\end{array}$ & -1182.5 & -1143.2 & -1144.4 & -28821.5 & -11436.8 & -30659.7 \\
\hline $\begin{array}{l}\text { Energia HOMO } \\
\text { (u.a.) }\end{array}$ & -0.222 & -0.223 & -0.184 & -0.199 & -0.199 & -0.203 \\
\hline $\begin{array}{l}\text { Energia LUMO } \\
\text { (u.a.) }\end{array}$ & -0.132 & -0.130 & -0.075 & -0.090 & -0.090 & -0.101 \\
\hline $\begin{array}{c}\text { GAP HOMO-LUMO } \\
\text { (u.a.) }\end{array}$ & 0.090 & 0.093 & 0.109 & 0.109 & 0.109 & 0.102 \\
\hline $\begin{array}{c}\text { GAP HOMO-LUMO } \\
(\mathrm{eV})\end{array}$ & 2.449 & 2.531 & 2.966 & 2.970 & 2.966 & 2.773 \\
\hline $\begin{array}{c}\text { Energia de } \\
\text { transição } \\
(\mathrm{eV})\end{array}$ & 2.449 & 2.531 & 2.966 & 2.970 & 2.966 & 2.773 \\
\hline Área $\left(\check{A}^{2}\right)$ & 510.17 & 482.73 & 510.11 & 660.1 & 626.39 & 732.72 \\
\hline Volume $\left(\dot{A}^{3}\right)$ & 847.76 & 799.97 & 859.05 & 1169.24 & 1090.42 & 1317.15 \\
\hline Carga total & 1 & 1 & -2 & -2 & -2 & -2 \\
\hline $\begin{array}{l}\text { Momento dipolo } \\
\text { (D) }\end{array}$ & 2.89 & 4.34 & 15.87 & 13.72 & 13.69 & 12.90 \\
\hline
\end{tabular}

Das propriedades calculadas para os corantes, podem ser destacadas as seguintes conclusões:

- Os valores de $\mathrm{ET}, \Delta \mathrm{H}_{\mathrm{f}}$, área e volume para os corantes fenotiazínicos são menores do que para os corantes xantenos (com exceção da FL). Estas 
propriedades são conseqüência direta do tamanho da molécula e do tamanho dos átomos que a compõem. Sendo assim, era de se esperar que esses valores fossem maiores para os xantenos, pois possuem um anel fenílico a mais e átomos mais pesados substituindo o hidrogênio (como bromo e iodo). A FL é uma exceção dos xantenos porque tem composição atômica semelhante à dos corantes fenotiazínicos;

- Como mencionado anteriormente, os orbitais de fronteira HOMO e LUMO indicam a capacidade mais elétron-doadora ou aceitadora de uma molécula. Os corantes não apresentam diferenças significativas quando comparados entre si utilizando como parâmetro as energias do HOMO. No entanto, as energias do LUMO indicam que os corantes fenotiazínicos recebem elétrons com maior facilidade, concordando com a noção de carga total $(+1$ para os fenotiazínicos e -2 para os xantenos, indicando que os últimos doariam elétrons mais facilmente);

- Em relação ao espectro de absorção, a transição eletrônica principal é uma transição entre HOMO e LUMO (note que o GAP HOMO-LUMO é igual à energia de transição).

A transição eletrônica principal destes corantes é uma transição HOMO-LUMO, portanto esta é a transição eletrônica que ocorre na absorção de luz destes compostos. Foi observado (Tabela 8) que as energias desses orbitais são inversamente proporcionais à "foto-atividade" dos corantes, ou seja, quanto menor o valor dessas energias, maior a atividade biológica 
Tabela 8: Comparação dos valores de $\mathrm{IC}_{50}$ no claro para 4h e $6 \mathrm{~h}$ de incubação em células HEp-2, dose de $18 \mathrm{~J} / \mathrm{cm}^{2}$ com os valores de energia dos orbitais de fronteira.

\begin{tabular}{|c|c|c|c|c|}
\hline Corante & $\begin{array}{c}\mathbf{I C}_{50} \text { claro para } \\
\mathbf{4 h} \\
(\mu \mathrm{g} / \mathrm{mL})\end{array}$ & $\begin{array}{c}\mathbf{I} \mathbf{C}_{50} \text { claro para } \\
\mathbf{6 h} \\
(\mu \mathrm{g} / \mathrm{mL})\end{array}$ & $\begin{array}{c}\text { HOMO } \\
(\text { u.a. })\end{array}$ & $\begin{array}{c}\text { LUMO } \\
(\text { u.a. })\end{array}$ \\
\hline Azul de Toluidina O & 0.7 & 0.12 & -0.223 & -0.130 \\
\hline Azul de Metileno & 10 & 1.4 & -0.222 & -0.132 \\
\hline Rose Bengal & 67 & 11 & -0.203 & -0.101 \\
\hline Eritrosina B & 124 & 74 & -0.199 & -0.09 \\
\hline Eosina Y & 213 & 104 & -0.199 & -0.09 \\
\hline Fluoresceína & 1644 & 370 & -0.184 & -0.075 \\
\hline
\end{tabular}

A Figura 12 apresenta a representação gráfica dos orbitais de fronteira (HOMO e LUMO). Observando as representações gráficas desses orbitais é possível verificar que, no caso dos fenotiazínicos, o HOMO está mais localizado nas extremidades do "antraceno" (chamando de "antraceno" a estrutura de três anéis fundidos) e o LUMO nos átomos do centro do "antraceno" (e para os xantenos o LUMO também está localizado nos átomos do anel fenílico), assim quando as moléculas absorvem energia, ocorre uma transferência de carga das extremidades para o centro de cada molécula. Analisando os gráficos da Figura 12 para os xantenos, verifica-se que os átomos de halogênio ligados no "antraceno" contribuem grandemente ao HOMO. 


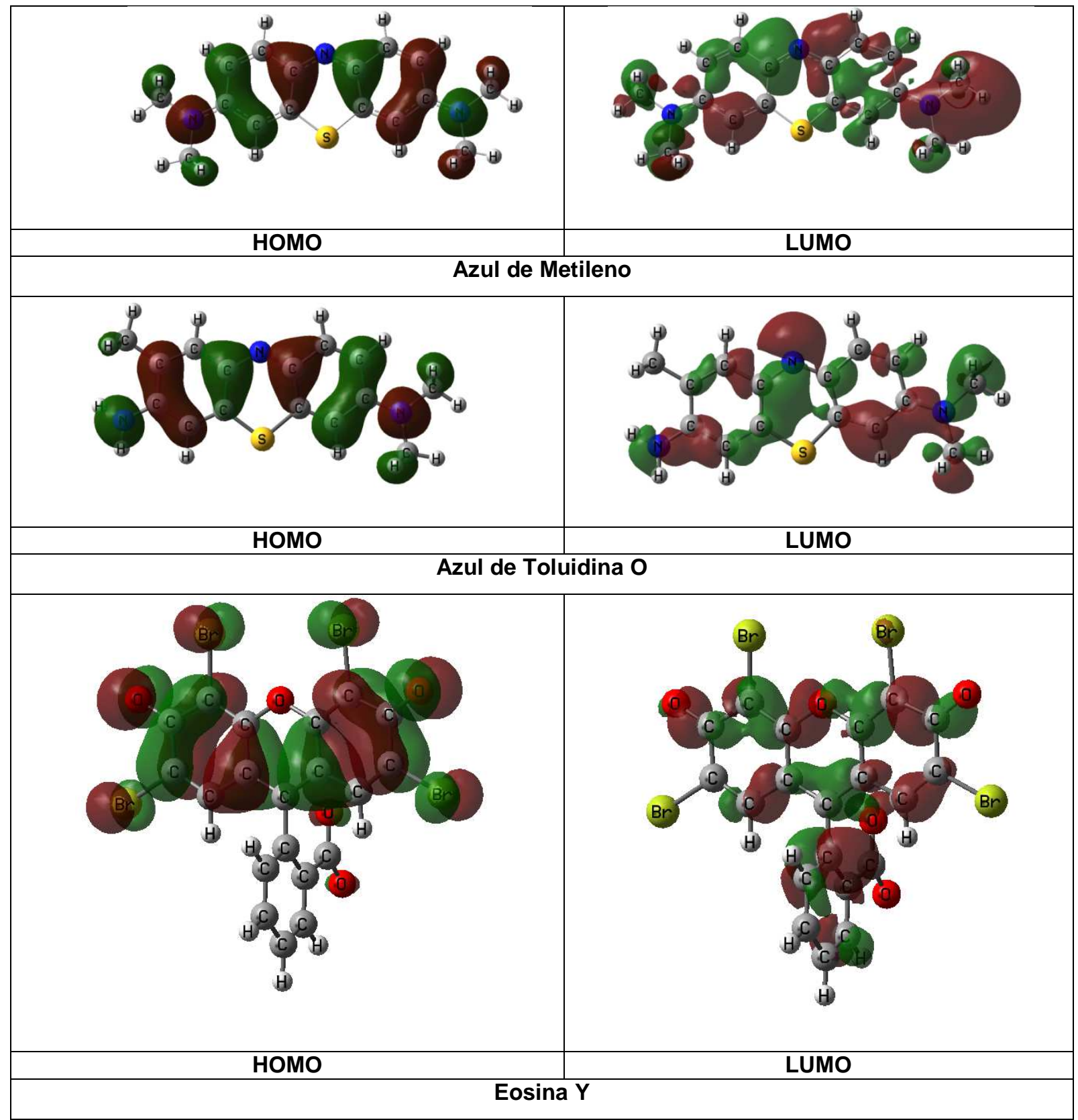




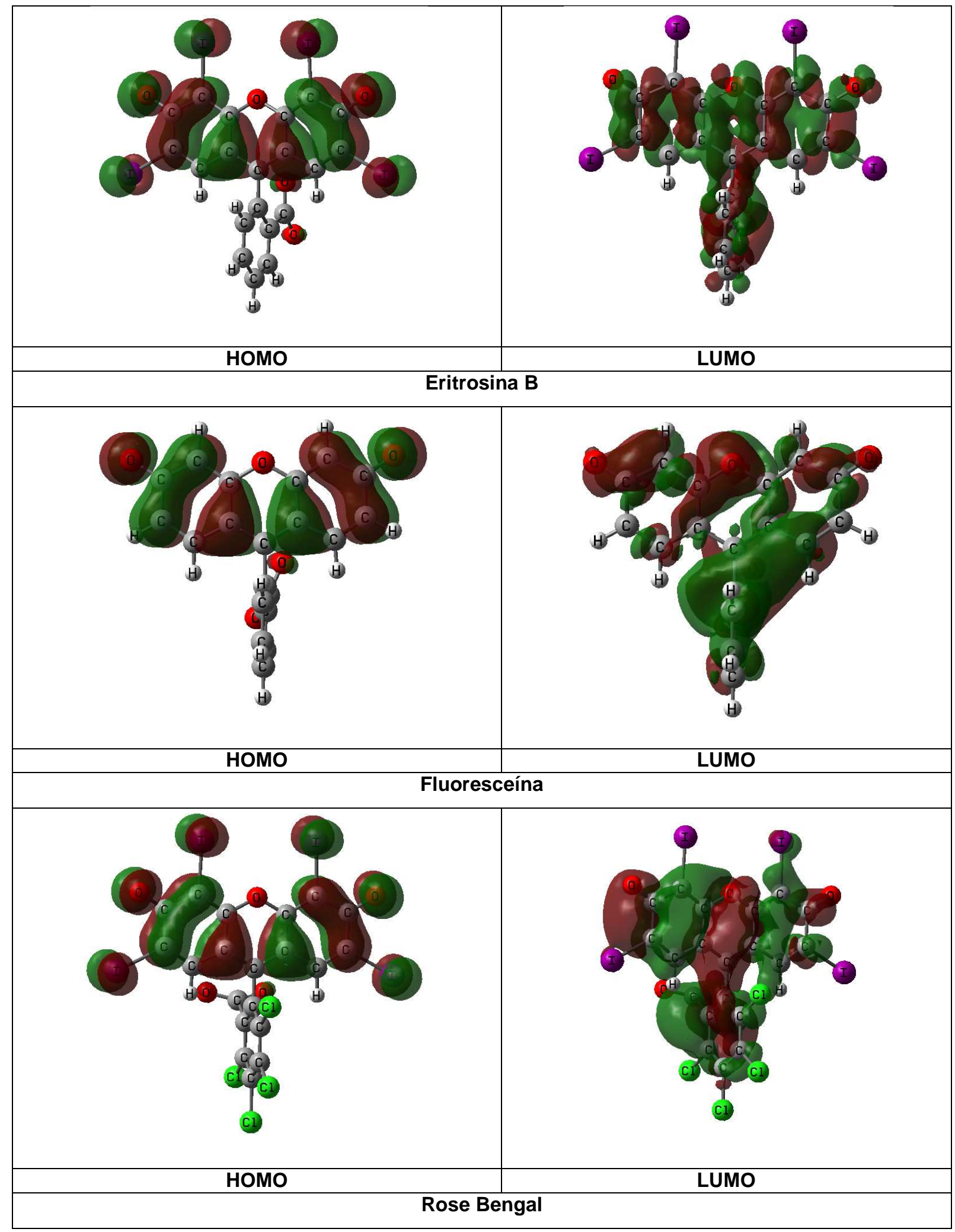

Figura 12. Representações gráficas dos orbitais de fronteira para as moléculas estudadas. 
Entretanto, como pode ser observado na Tabela 8 e na Figura 12, os orbitais HOMO e LUMO são bem parecidos para o AM e ATO e para a RB, ER e EY e, portanto, as propriedades relacionadas a eles não ofereceram explicação para as diferenças nas atividades biológicas dentro das famílias de corantes.

A substituição de um átomo, em uma dada estrutura, por outro de maior número atômico leva a um aumento no rendimento quântico de ${ }^{1} \mathrm{O}_{2}$. Em moléculas eletronicamente excitadas, o acoplamento spin-órbita facilita o cruzamento intersistemas, permitindo assim mudanças, de outro modo, proibidas no spin eletrônico (singlete-triplete). A constante de acoplamento spin-órbita é proporcional a quarta potência do número atômico do elemento de interesse, sendo assim, a presença de um "átomo pesado" (iodo ou bromo) em uma molécula aumenta o grau de acoplamento spin-órbita ${ }^{29,44}$. Como $0{ }^{1} \mathrm{O}_{2}$ é uma espécie extremamente citotóxica, um aumento na sua produção implica em maior atividade biológica do composto substituído. Este fator explica a diferença na atividade biológica dentro da família dos corantes xantenos e pode melhor ser visualizada através da figura 13. 


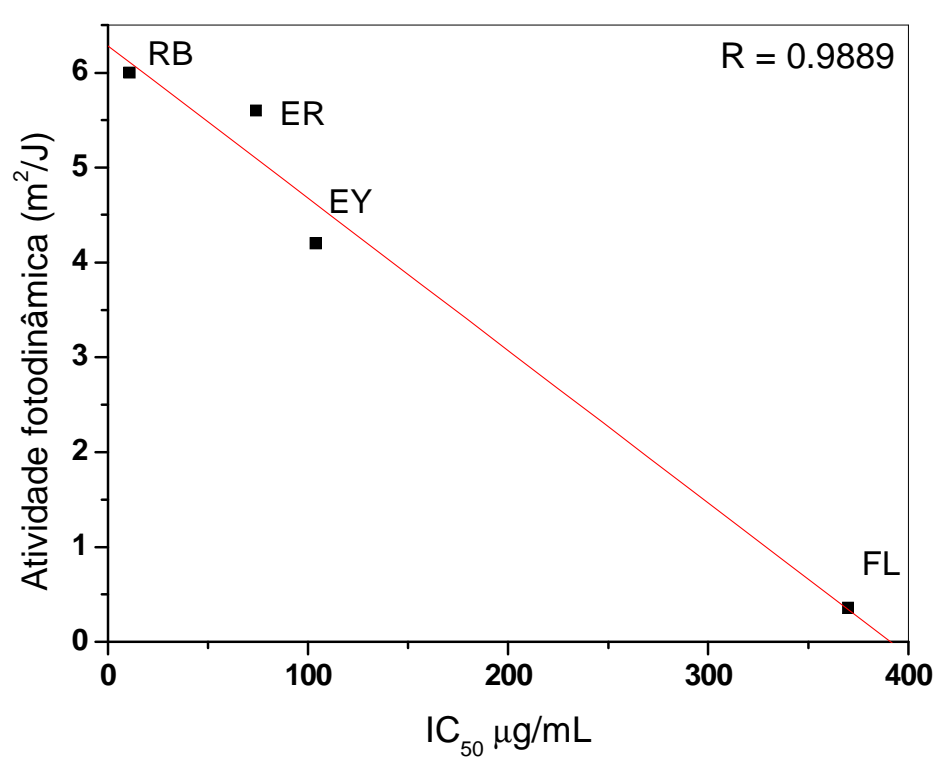

Figura 13. Gráfico de atividade fotodinâmica em função de $I C_{50}$ no claro para 6 hrs de incubação com células HEp-2, com corantes xantenos.

Como foi visto anteriormente, a AF está relacionada com a produção de ${ }^{1} \mathrm{O}_{2} \mathrm{e}$ através do gráfico acima pode-se observar que quanto maior a AF maior o efeito citotóxico do $\mathrm{FS}$ (valor menor de $\mathrm{IC}_{50}$ ). A FL que não possui nenhum substituinte em sua estrutura tem o menor valor de AF, sendo também o composto menos citotóxico. Já o RB possui quatro átomos de iodo e quatro de cloro em sua estrutura; possuindo, portanto, valores maiores de AF e sendo também o mais citotóxico em comparação aos demais.

A análise de outros parâmetros, nominalmente o volume, a área e as cargas atômicas destas moléculas, pode ainda ser feita para explicar as diferenças nas atividades biológicas entre os corantes fenotiazínos e os xantenos. Os corantes fenotiazínicos são moléculas pequenas em comparação com os xantenos, esta característica pode facilitar a difusão dos fenotiazínicos através da membrana plasmática e o acúmulo nas organelas celulares, concordando com a literatura que 
mostra que a localização do AM e ATO é nos lisossomos e no núcleo celular ${ }^{33,38,40,41}$. Já os compostos mais volumosos podem oferecer algum impedimento estérico para a difusão através da membrana, também concordando com a literatura que diz que os xantenos tendem a se localizar na membrana plasmática ${ }^{55,61,62}$, onde o dano provocado durante a PDT pode ser reversível.

A Figura 14 apresenta as cargas atômicas derivadas do potencial eletrostático $(\mathrm{CHELPG})^{114}$.

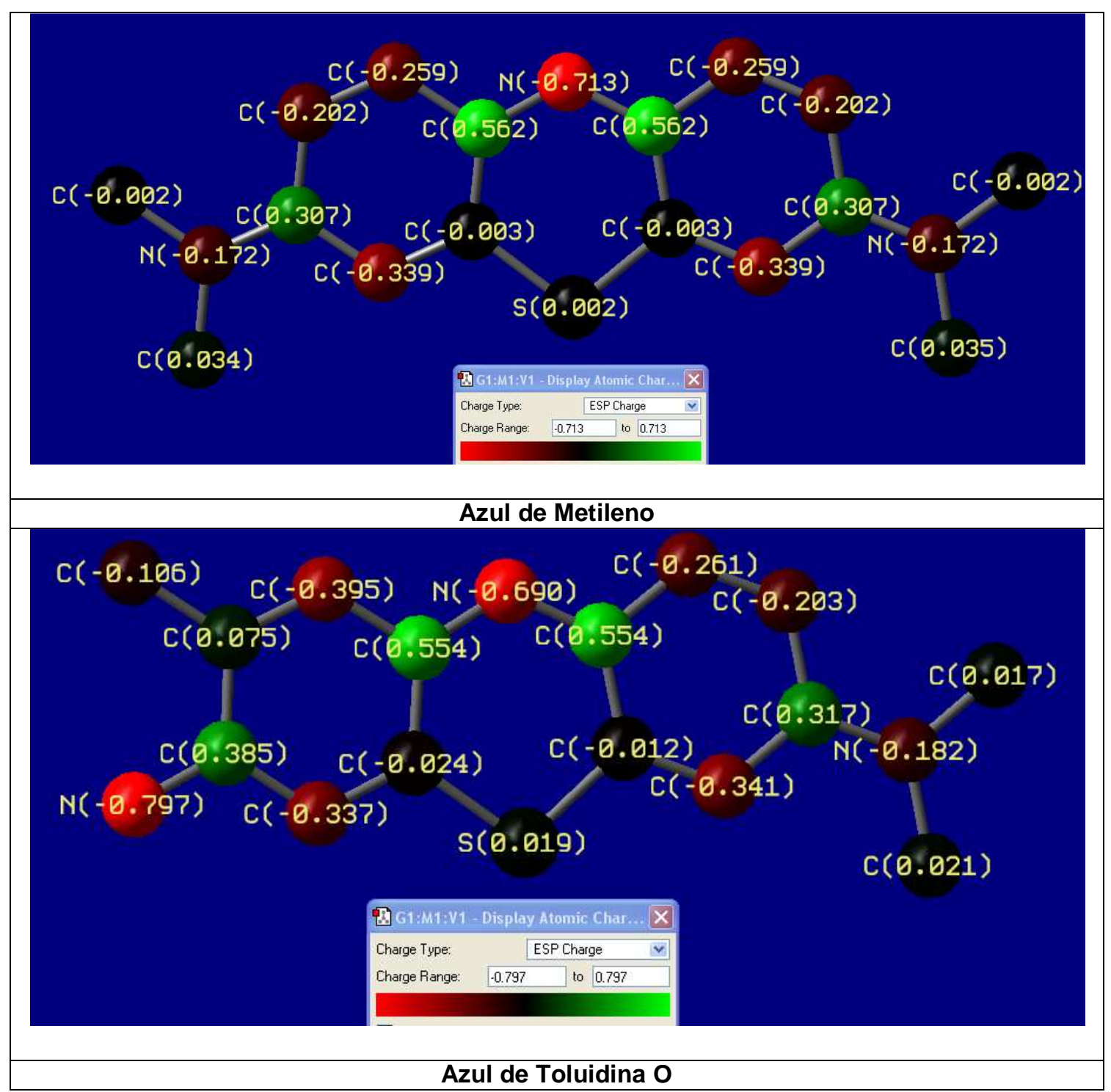




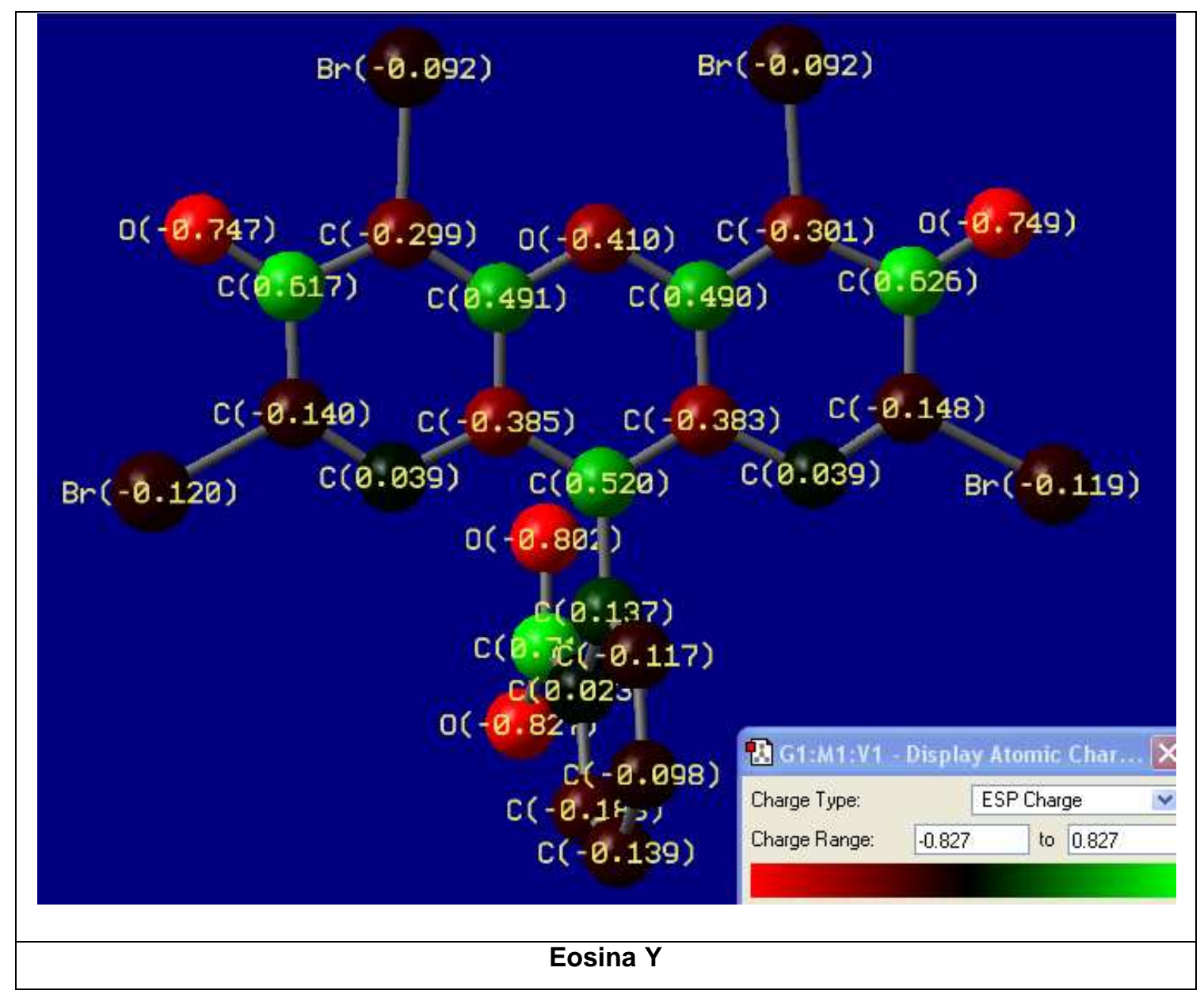




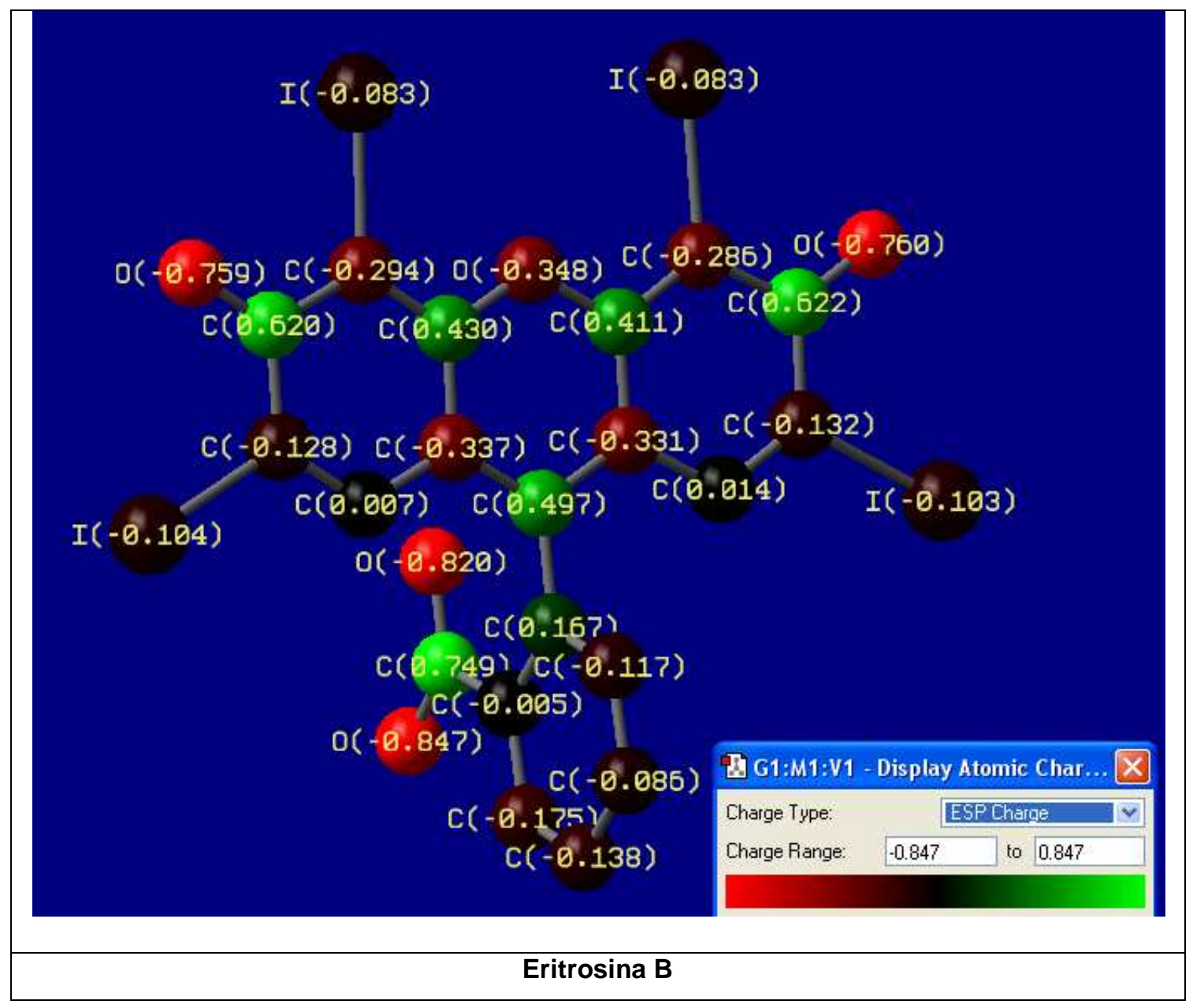




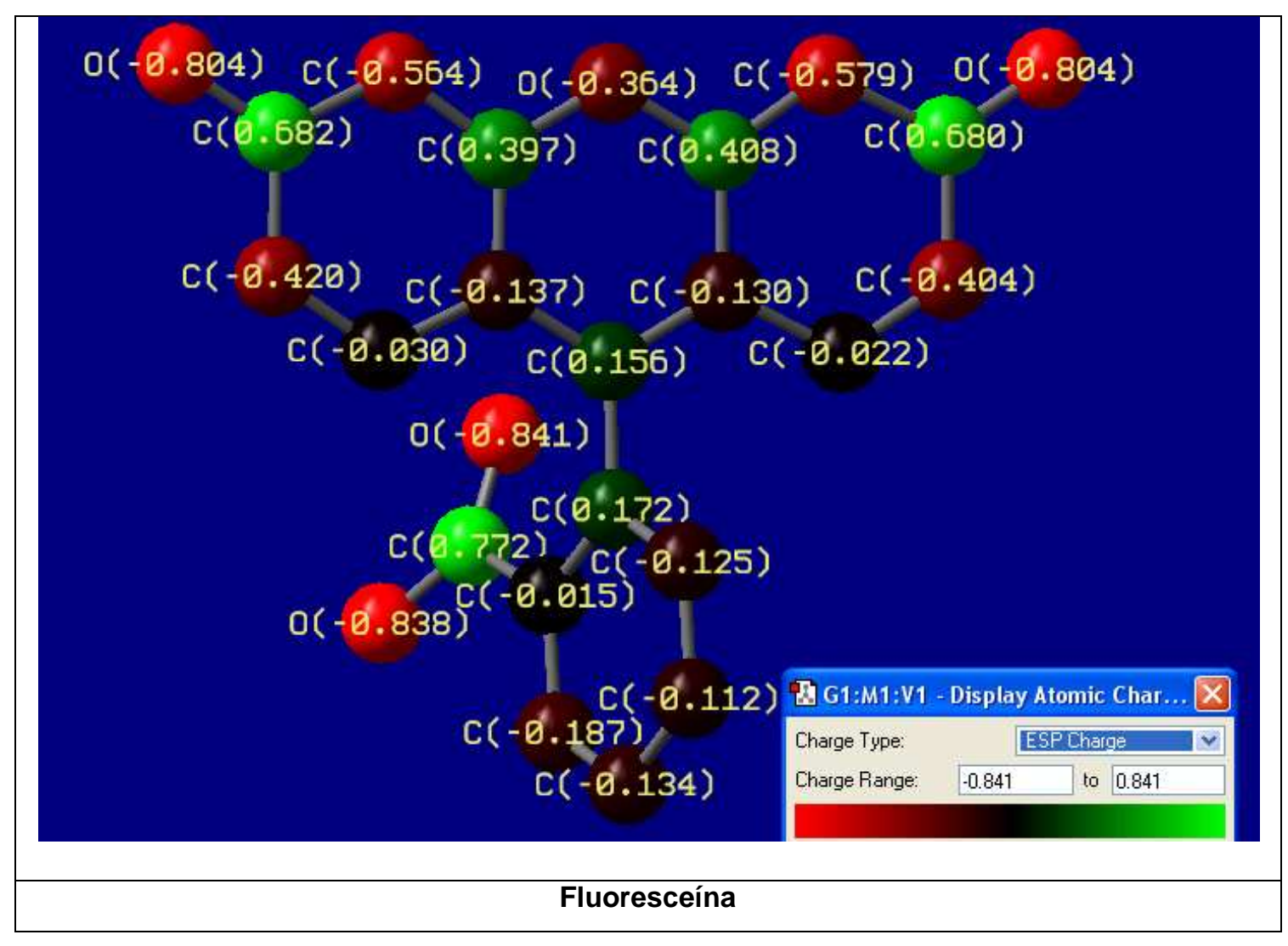




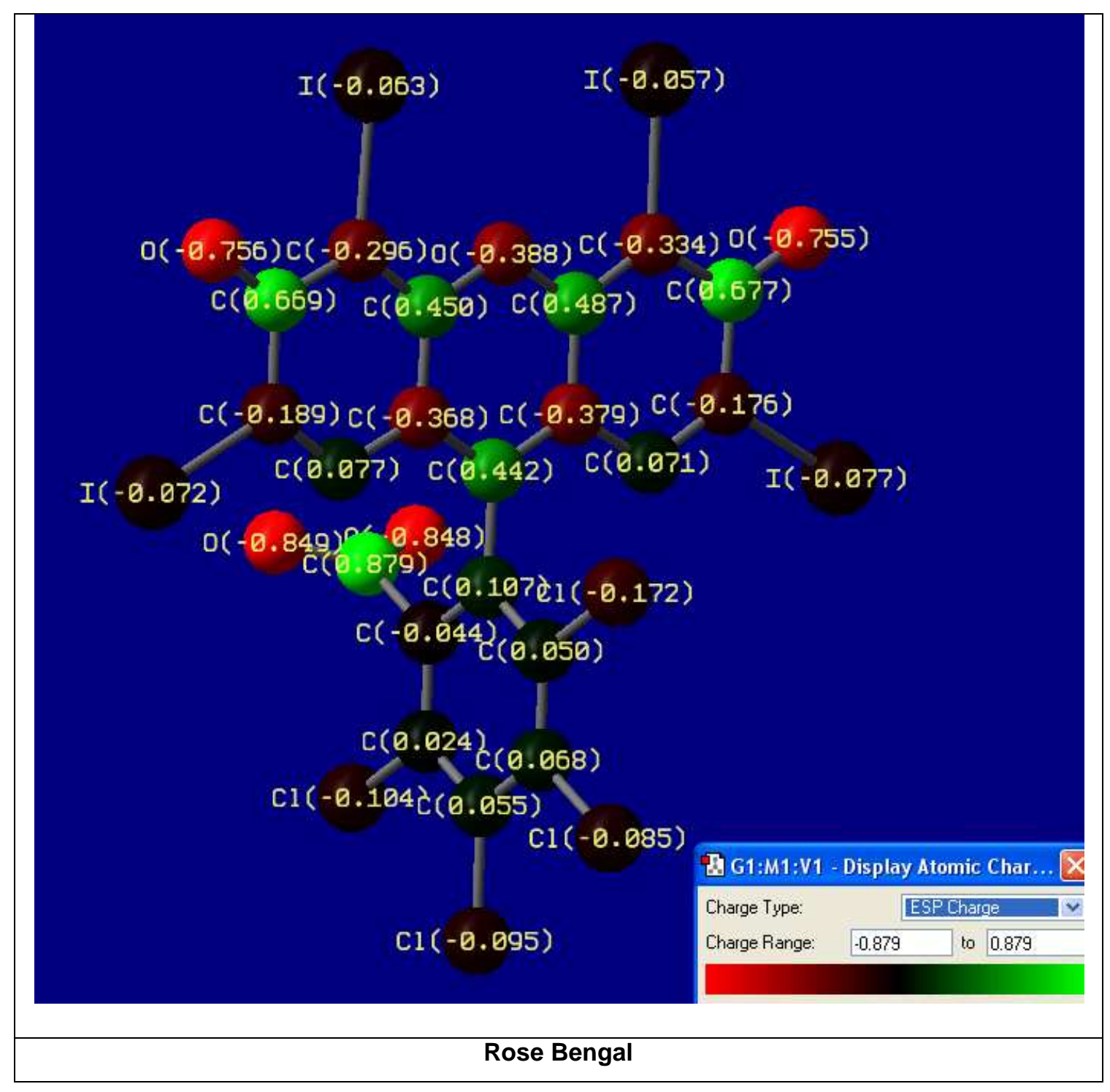

Figura 14. Cargas atômicas para as moléculas estudadas (átomos de hidrogênio omitidos).

O corante AM, por ser bastante simétrico, apresenta cargas distribuídas também simetricamente. Por conta da assimetria dos ligantes dos anéis fundidos, o ATO apresenta uma distribuição de carga assimétrica; portanto, era de se esperar que o ATO fosse menos hidrofóbico que o $\mathrm{AM}$, pois além de ter momento de dipolo maior apresenta um grupo $\mathrm{NH}_{2}$ que pode fazer ligação de hidrogênio com a água. 
Os xantenos apresentam momentos de dipolo maiores do que os fenotiazínicos, pois possuem carga total maior (em módulo), portanto os fenotiazínicos são menos polares, explicando assim sua maior hidrofobicidade em relação aos xantenos. A hidrofobicidade do RB em contraste com a hidroficilidade dos outros xantenos estudados pode ser explicada pela presença dos átomos de cloro no anel, pois apesar de ser uma molécula bem polar, estes átomos provavelmente oferecem certo impedimento estérico para a interação com a água. Além disso, a substituição de átomos de hidrogênio por halogênios nas moléculas que compõem essa família faz com que o momento de dipolo diminua. É interessante notar que essa substituição faz com que a posição dos átomos de oxigênio do ácido carboxílico também seja alterada. 


\section{CONCLUSÕES}

Neste estudo foram empregados quatro métodos para avaliar a eficiência fotodinâmica de seis corantes com potencial uso em PDT. A determinação da concentração inibitória média $\left(\mathrm{IC}_{50}\right)$ na linhagem de células tumorais HEp-2 foi utilizada para avaliar a citotoxicidade dos corantes. O experimento de fotoxidação do ácido úrico para obter a atividade fotodinâmica foi utilizado para se avaliar a produção de oxigênio singlete pelos corantes. Foi investigada também a interação dos fotossensibilizadores com BSA como modelo de proteína. A determinação do coeficiente de partição permitiu obter-se, uma medida do caráter lipofílico destes compostos. Os estudos teóricos foram realizados com o objetivo de compreender melhor a estrutura dos corantes estudados. Foram feitas relações, quando possível, com os dados experimentais, fornecendo subsídios para o planejamento de novos e melhores compostos para serem utilizados como FS em PDT.

Os estudos teóricos mostraram que para o planejamento de novos fotossensibilizadores, seria ideal procurar por moléculas pequenas e com carga positiva, pois estas características facilitam a difusão pela membrana plasmática e o acúmulo nas organelas celulares, com momento de dipolo não muito elevado, contribuindo assim para a hidrofobicidade do composto e com substituintes com número atômico maior, para se obter maior produção de oxigênio singlete. Obviamente nem todas estas mudanças estruturais podem ser feitas em uma única molécula, cabendo ao pesquisador analisar a propriedade mais desejada para o planejamento ou otimização de moléculas para serem utilizadas como fotossensibilizadores. 
Com base nos resultados obtidos e nas discussões apresentadas, conclui-se que os corantes fenotiazínicos são fotossensibilizadores mais eficientes que os corantes xantenos, sendo que, algumas mudanças estruturais poderiam ser feitas no AM e ATO a fim de melhorar sua atividade fotodinâmica. No entanto, deve-se levar em consideração que a aplicação in vivo de um FS envolve inúmeros parâmetros, tais como: estruturas complexas, meios de aplicação, efeitos colaterais, administração tópica ou sistêmica do FS, etc., que devem ser cuidadosamente avaliados e podem ser modificados até a obtenção do melhor resultado. Sendo assim, os corantes fenotiazínicos podem ser considerados como possíveis alvos de estudo visando à aplicação em PDT. 


\section{REFERÊNCIAS BIBLIOGRÁFICAS}

1. ALBERTS, B.; JOHNSON, A.; LEWIS, J.; RAFF, M.; ROBERTS, K.; WALTER, P. Biologia molecular da célula. Porto Alegre: Artmed, 2004, 4.ed.,cap.23.

2. www.cancer.gov - acessada em outubro/2008.

3. SHARMAN, W.M.; ALLEN, C.M.; VAN LIER, J.E. Photodynamic therapeutics: basic principles and clinical applications. DDT, v.4, p.507-517, 1999.

4. BUYTAERT, E.; DEWAELE, M.; AGOSTINIS, P. Molecular effectors on multiple cell death pathways initiated by photodynamic therapy. Biochimica et Biophysuca Acta, v. 1776, p. 86-107, 2007.

5. CASTANO, A.P.; DEMIDOVA, T.N.; HAMBLIN, M.R. Mechanisms in photodynamic therapy: part: two - cellular signaling, cell metabolism and modes of cell death.

Photodiagnosis and Photodynamic Therapy, v.2, p.1-23, 2005.

6. DOLMANS, D.E.J.G.; FUKUMURA, D.; JAIN, R.K. Photodynamic therapy for cancer. Nature Reviews. Cancer, v. 3, p.380-387, 2003.

7. STARK, G. Functional consequences of oxidative membrane damage. Journal of Membrane Biology, v.205, p.1-16, 2005

8. CASTANO, A.P.; DEMIDOVA, T.N.; HAMBLIN, M.R. Mechanisms in photodynamic therapy: part: one - photosensitizers, photochemistry and cellular localization.

Photodiagnosis and Photodynamic Therapy, v.1, p.279-293, 2004.

9. RAVANAT, J.L.; DI MASCIO, P.; MARTINEZ, G.R.; MEDEIROS, M.H.G.; CADET, J. Singlet oxygen induces oxidation of cellular DNA. The journal of Biological Chemistry, v.275, p.40601-40604, 2000.

10. KONAN, Y.N.; GURNY, R.; ALLÉMANN, E. State of the art in the delivery of photosensitizers for photodynamic therapy. Journal of Photochemistry and

Photobiology B: Biology, v.66, p.89-106, 2002. 
11. MACCORMACK, M.A. Photodynamic therapy. Advances in Dermatology, v.22, p.219-258, 2006.

12. CALZAVARA-PINTON, P.G.; VENTURINI, M. ; SALA, R. A comprehensive overview of photodynamic therapy in the treatment of superficial fungal infections of the skin. Journal of Photochemistry and Photobiology B: Biology, v.78, p.1-6, 2005.

13. DEMIDOVA, T.N.; HAMBLIN, M.R. Effect of cell-photosensitizer binding and cell density on microbial photoinactivation. Antimicrobial Agentes and Chemotherapy, v.49, p.2329-2335, 2005.

14. WAINWRIGHT, M. Photodynamic antimicrobial chemoterapy (PACT). Journal of Antimicrobial Chemotherapy, v.42, p.13-28, 1998.

15. DONNELLY, R.F.; McCARRIN, P.A.; TUNNEY, M.M. Antifungal photodynamic therapy. Microbiological Research, v.163, p.1-12, 2008.

16. PERUSSI, J.R. Inativação Fotodinâmica de Microorganismos. Química Nova, v.30, n.4, p.988-994, 2007.

17. PERUSSI, J. R.; IMASATO, H . Inativação fotodinâmica de microrganismos. In: Vanderlei Bagnato. (Org.). Novas Técnicas Ópticas para as áreas da saúde. São Carlos: Livraria da Física - Editora, 2008, v. 01, p. 163-183.

18. KÜBLER, A.C. Photodynamic therapy. Medical Laser application, v.20, p.37-45, 2005.

19. ALLEN, N.S.; MCKELLAR, J.F. Photochemistry of dyes and pigmented polymers. Londres: Applied Science Publishers LTD, 1980, Cap.1.

20. SIMPLICIO, F.I.; MAIONCHI, F.; HIOKA, N. Terapia fotodinâmica: aspectos farmacológicos, aplicações e avanços recentes no desenvolvimento de medicamentos. Química Nova, v.25, p.801-807, 2002. 
21. DEROSA, M.C.; CRUTCHLEY, R.J. Photosensitized singlet oxygen and its applications. Coordination Chemistry Reviews, v.233-234, p.351-371, 2002.

22. LUKŠIENÉ, Ž. New approach to inactivation of harmful and pathogenic microorganisms by photosensitization. Food Technology and Biotechnology, v. 43, 411-418, 2005.

23. JIMÉNEZ-BANZO, A.; SAGRISTÀ, M.L.; MORA, M.; NONELL, S. Kinects of singlet oxygen photosensitization in human skin fibroblasts. Free Radical Biology \& Medicine, v. 44, p.1926-1934, 2008.

24. NIEDRE, M.J.; SECORD, A.J.; PATTERSON, M.S.; WILSON, B.C. In vitro tests of the validity of singlet oxygen luminescense measurements as a dose metric in photodynamic therapy. Cancer Research, v.63, p.7986-7994, 2003.

25. MACHADO, A.E.H. Terapia fotodinâmica: Princípios, potencial de aplicações e perspectivas. Química Nova, v.23, p.237-243, 2000.

26. NAGATA, S.; OBANA, A.; GOHTO, Y.; NAKAJIMA, S. Necrotic and apoptotic cell death of human malignant melanoma cells following photodynamic therapy using na amphiphilic photosensitizer, ATX-S10(Na). Lasers in Surgery and Medicine, v.33, p.64-70, 2003.

27. JUZENIENE, A.; MOAN, J. The history of PDT in Norway Part one: Identification of basic mechanisms of general PDT. Photodiagnosis and Photodynamic Therapy, v.4, p.3-11, 2007.

28. ALLISON, R.R.; DOWNIE, G.H.; CUENCA, R.; HU, X,H.; CHILDS, C.JH.; SIBATA, C.H. Photosensitizers in clinical PDT. Photodiagnosis and Photodynamic Therapy, v.1, p.27-42, 2004.

29. DETTY, M.R.; GIBSON, S.L.; WAGNER, S.L. Current clinical and preclinical photosensitizers for use in photodynamic therapy. Journal of Medicinal Chemistry, v.47, p.3897-3915, 2004.

30. DE ROSA, F.S.; BENTLEY, V.L.B. Photodynamic therarapy of skin cancers: Sensitizers, clinical studies and future directives. Pharmaceutical Research, v.17, p.1447-1455, 2000. 
31. MEISEL, P.; KOCHER, T. Photodynamic therapy for periodontal diseases: State of the art. Journal of Photochemistry and Photobiology B: Biology, v.79, p.159-170, 2005.

32. TARDIVO, J.P.; DEL GIGLIO, A.; OLIVEIRA, C.S.; GABRIELLI, D.S.; JUNQUEIRA, H.C.; TADA, D.B.; SEVERINO, D.; TURCHIELLO, R.F.; BAPTISTA, M.S. Methylene blue in photodynamic therapy: From basic mechanisms to clinical applications.

Photodyagnosis and Photodynamic Therapy, v.2, p.175-191, 2005.

33. WALKER, I.; GORMAN, S.A.; COX, R.D.; VERNON, D.I.'GRIFFITHS, J.; BROWN, S.B. A comparative analysis of phenothiazinium salts for the photosensitisation of murine fibrosarcoma (RIF-1) cells in vitro. Photochemical and Photobiological Sciences, v.3, p.653-659, 2004.

34. HUSSAIN, S. HARRIS, F, PHOENIX, D.A. The phototoxicity of phenothiaziniumbased photosensitizers to bacterial membranes. FEMS Immunology and Medical Microbiology, v.46, p.124-130, 2006.

35. PHOENIX, D.A.; SAYED, Z.; HUSSAIN, S.; HARRIS, F.; WAINWRIGHT, M. The phototoxicity of phenothiazinium derivatives against Escherichia coli and Staphylococcus aureus. FEMS Immunology and Medical Microbiology, v.39, p.17-22, 2003.

36. WAINWRIGHT, M.; GIDDENS, R.M. Phenothiazinium photosensitisers: choice in synthesis and application. Dyes and Pigments, v.57, p.245-257, 2003.

37. WAINWRIGHT, M. Phenothiazinium photosensitisers: V. Photobactericidal activities of chromophore-methylated phenothiazinium salts. Dyes and Pigments, v.73, p.7-12, 2007.

38. HARRIS, F.; SAYED, Z.; HUSSAIN, S.; PHOENIX, D.A. An investigation into the potential of phenothiazinium-based photo-sensitisers to act as PDT agents.

Photodiagnosis and Photodynamic Therapy, v.1, p.231-239, 2004.

39. ALLINGER, N.L. Química Orgânica. Rio de Janeiro: Guanabara dois S.A., 1978, 5.ed., cap.11. 
40. MELLISH, K.J.; COX, R.D.; VERNON, D.I.; GRIFFITHS, J.; BROWN, S.B. In vitro pohodynamic activity of a series of methylene blue analogues. Photochemistry and Photobiology, v.75, p.392-397, 2002.

41. WAINWRIGHT, M.; PHOENIX, D.A.; RICE, L.; BURROW, S.M.; WARING, J. Increased cytotoxicity and phototoxicity in the methylene blue series via chromophore methylation. Journal of Photochemistry and Photobiology B: Biology, v.40, p.233239, 1997.

42. ORTH, K.; RÜCK, A. STANESCU, A.; BEGER, H.G. Intraluminal treatment of inoperable oesophageal tumours by intralesional photodynamic therapy with methylene blue. The Lancet, v.345, p.519-520, 1995.

43. WAINWRIGHT, M. The development of phenothiazinium photosensitisers. Photodiagnosis and Photodynamic Therapy, v.2, p.263-272, 2005.

44. WAINWRIGHT, M. Non-porphyrin photosensitizers in biomedicine. Chemical Society Reviews, v.25, p.351-359, 1996.

45. TANG, W.; XU, H.; PARK, E.J.; PHILBERT, M.A.; KOPELMAN, R. Encapsulation of methylene blue in polyacrylamide nanoparticle platforms protects its photodynamic effectiveness. Biochemical and Biophysical Research Communications, v.369, p.579-583, 2008.

46. USACHEVA, M.N.; TEICHERT, M.C.; BIEL, M.A. Comparison of the methylene blue and toluidine blue photobactericidal efficacy against gram-positive and gram-negative microorganisms. Lasers in Surgery and Medicine, v.29, p.165-173, 2001.

47. WAINWRIGHT, M.; PHOENIX, D.A.; MARLAND, J.; WAREING, D.R.A.; BOLTON, F.J. A study of photobactericidal activity in the phenothiazinium series. FEMS Immunology and Medical Microbiology, v.19, p.75-82, 1997.

48.TEICHERT, M.C.; JONES, J.W.; USACHEVA, M.N.; BIEL, M.A. Treatment of oral candidiasis with methylene blue-mediated photodynamic therapy in an immunodeficiente murine model. Oral Surgery Oral Medicine Oral Phatology, v.93, p.155-160, 2002. 
49. WAINWRIGHT, M.; GRICE, N.J.; PYE, L.E.C. Phenothiazine photosensitizers: part 2. 3,7-Bis(arylamino)phenothiazines. Dyes and Pigments, v.42, p.45-51, 1999.

50. WAINWRIGHT, M. The use of dyes in modern biomedicine. Biotechnic \& Histochemistry, v.78, p.147-155, 2003.

51. WILSON, M.; MIA, N. Sensitisation of Candida albicans to killing by low-power light. Journal of Oral Phatology and Medicine, v.22, p.354-357, 1993.

52. WILSON, M. Lethal photosensitisation of oral bacteria and its potential application in the photodynamic therapy of oral infections. Photochemical and Photobiological Sciences, v.3, p.412-418, 2004.

53. KOMERICK, N.; WILSON, M. Factors influencing the susceptibility of Gram-negative bacteria to toluidine blue O-mediated lethal photosensitization. Journal of Applied microbiology, v.92, p.618-623, 2002

54. DIWU, Z.; LOWN, J.W. Phototherapeutic potential of alternative photosensitizers to porphyrins. Pharmacology Therapeutical, v.63, p.1-35, 1994.

55. WANG, H.; LU, L.; ZHU, S.; LI, Y.; CAI, W. The phototoxicity of xanthene derivatives against Escherichia coli, Staphylococcus aureus and Saccharomyces cerevisiae.

Currente Microbiology, v.52, p.1-5, 2006.

56. UESUGI, N.; FURUMIYA, K.; MIZUTANI, T. Inhibition mechanism of UDPGlucuronosyltransferase $1 \mathrm{~A} 6$ by xanthene food dyes. Journal of Health Science, v.52, p.549-557, 2006.

57. SUGITA, N.; KAWABATA, K.;SASAKI, K.; SAKATA, I.; UMEMURA, S. Synthesis of amphiphilic derivatives of rose bengal and their tumor accumulation. Bioconjugate Chemistry, v.18, p.866-873, 2007.

58. CHANG, C.; YANG, Y.; YANG, J.; WU, H.; TSAI, T, Absorption and emission spectral shifts of rose bengal associated with DMPC liposomes. Dyes and Pigments, v.79, p.170-175, 2008. 
59. WACHTER, E.; DEES, C.; HARKINS, J.; SCOTT, T.; PETERSEN, M.; RUSH, R.E.; CADA, A. Topical rose bengal: Pre-clinical evaluation of pharmacokinetics and safety. Lasers in Surgery and Medicine, v.32, p.101-110, 2003.

60. PAULINO, T.P.; RIBEIRO, K.F.; THEDEI JR., G.; TEDESCO, A. C.; CIANCAGLINI, $P$. Use of hand held photopolymerizer yo photoinactivate Streptococcus mutans.

Archives of Oral Biology, v.50, p.353-359, 2005.

61. TSENG, S.C.G.; FEENSTRA, R.P.G.; WATSON, B.D. Characterization of photodynamic actions of rose bengal on cultured cells. Investigative Ophtalmology \& Visual Science, v.35, p.3295-3307, 1994.

62. SCHÄFER, M.; SCHMITZ, C.; FACIUS, R.; HORNECK, G.; MILOW, B.; FUNKEN, K.H.; ORTNER, J. Systematic study of parameters influencing the action of rose bengal with visible light on bacterial cells: Comparison between the biological effect and singlet oxygen production. Photochemistry and Photobiology, v.71, p.514-523, 2000.

63. GAO, D.; TIAN, Y.; LIANG, F.; JIN, D.; CHEN, Y.; ZHANG, H.; YU, A. Investigation of the $\mathrm{pH}$ dependent binding of eosin $\mathrm{Y}$ and bovine serum albumin by spectral methods. Journal of Luminescence, v.127, p.515-522, 2007.

64. STYLLI, S.S.; KAYE, A, H. Photodynamic therapy of cerebral glioma - A review Part I - A biological basis. Journal of Clinical Neuroscience, v. 13, p. 615-625, 2006.

65. BONNEAU, S.; MORLIÈRE, P.; BRAULT, D. Dynamics of interactions of photosensitizers with lipoproteins and membrane-models: correlation with cellular incorporation and subcellular distribution. Biochemical Pharmacology, v.68, p.14431452, 2004.

66. CASTANO, A.P.; DEMIDOVA, T.N.; HAMBLIN, M.R. Mechanisms in photodynamic therapy: Part three - photosensitizers pharmacokinetics, biodistribution, tumor localization and modes of tumor destruction. Photodiagnosis and Photodynamic Therapy, v.2, p.91-106, 2005.

67. MAZIĖRE, J.C.; MORLIÈRE, P.; SANTUS, R. New trends in photobiology (invited review), the role of the low density lipoprotein receptor pathway in the delivery of lipophilic photosensitizers in the photodynamic therapy of tumours. Journal of Photochemistry and Photobiology B: Biology, v. 8, p.351-360, 1991. 
68. BONNEAU, S.; VEVER-BIZET, C.; MORLIÈRE, P.; MAZIÈRE, J.C.; BRAULT, D. Equilibrium and kinetic studies of the interactions of a porphyrin with low-density lipoproteins. Biophysical Journal, v. 83, p.3470-3481, 2002.

69. VITOLS, S.; PETERSON, C.; LARSSON, O.; HOLM, P.; ABERG, B. Elevated uptake of low density lipoproteins by human lung cancer tissue in vivo. Cancer Research, v. 52, p.6244-6247, 1992.

70. TSUCHIDA, T.; ZHENG, G.; PANDEY, R.K.; POTTER, W.R.; BELLNIER, D.A.; HENDERSON, B.W.; KATO, H.; DOUGHERTY, T.J. Correlation between site II-specific human serum albumin (HAS) binding affinity and murine in vivo photosensitizing efficacy of some photofrin ${ }^{\circledR}$ components. Photochemistry and Photobiology, v.66, p.224-228, 1997.

71. POLO, L.; VALDUGA, G.; JORI, G.; REDDI, E. Low-density lipoprotein receptors in the uptake of tumour photosensitizers by human and rat transformed fibroblasts. The International Journal of Biochemistry \& Cell Biology, v.34, p.10-23, 2002.

72. POTTIER, R.; KENNEDY, J.C. New trends in photobiology (invited review), the possible role of ionic species in selective biodistribution of photochemotherapeutic agents toward neoplastic tissue. Journal of Photochemistry and Photobiology B: Biology, v.8, p.1-16, 1990.

73. SINGH, T.S.; MITRA, S. Fluorimetric studies on the binding of 4(dimethylamino)cinnamic acid with micelles and bovine serum albumin. Photochemical \& Photobiological Sciences, v. 7, p.1063-1070, 2008.

74. OGUNSIPE, A.; NYOKONG, T. Photophysicochemical consequences of bovine serum albumin binding to non-transition metal phthalocyanine sulfonates.

Photochemical \& Photobiological Sciences, v.4, p.510-516, 2005.

75. GAO, D.; TIAN, Y.; BI, S.; CHEN, Y.; YU, A.; ZHANG, H. Studies on the interaction of colloidal gold and serum albumins by spectral methods. Spectrochimica Acta Part A, v.62, p.1203-1208, 2005.

76. CAVALCANTE, R.S. Avaliação da eficiência fotodinâmica de fotossensibilizadores com aplicação em terapia fotodinâmica. 2007. Dissertação (Química Analítica São Carlos) - Universidade de São Paulo. 
77. CAVALCANTE, R.S., IMASATO, H., BAGNATO, V.S., PERUSSI, J. R. A combination of techniques to evaluate photodynamic efficiency of photosensitizers. Laser Physics Letters, v. 6(1), 2008 (on line). DOI 10.1002.

78. BECKER, B. F.; Towards the physiological function of uric acid. Free Radical Biology \&Medicine, v.14, p.615-631, 1993.

79. KANOFSKY, J. R. Quenching of singlet oxygen by human plasma. Photochemistry and Photobiology, v.51, p.299-303, 1990.

80. NERI, C.R.; PRADO, A.P.J.M.; RIBEIRO, A.O.; SERRA, O.A.; IAMAMOTO, Y. Determination of the photodynamic activity of porphyrins : Potential photosensitizers for treatment of age-related macular degeneration. Material Science, v.20, p.69-75, 2002.

81. FISCHER, F.; GRASCHEW, G.; SINN, H.J.; MAIER-BORST, W.; LORENZ, W.J.; SCHLAG, P.M. A chemical dosimeter for the determination of the photodynamic activity of photosensitizers. Clinica Chimica Acta, v.274, p.89-104, 1988.

82.TAVARES, L.C. QSAR: A abordagem de Hansch. Química Nova, v.27, p.631-639, 2004.

83. SILVERMAN, R.B. The organic chemistry of drug design and drug action. San Diego: Academic Press, 1992, p.26-34.

84. HUDSON, R.; SAVOIE, H.; BOYLE, R.W. Lipophilic cationic porphyrins as photodynamic sensitisers - Synthesis and structure-activity relationships.

Photodiagnosis and Photodynamic Therapy, v.2, p.193-196, 2005.

85. HOMEM-DE-MELLO, P. Estudo teórico sobre a interação de corantes em argilas. São Carlos, 2002. Dissertação (Mestrado)-Instituto de Química de São Carlos, Universidade de São Paulo.

86. LEVINE, I.N. Quantum Chemistry. New York, Prentice Hall, 4. ed., 1991, p.342346.

87. SZABO, A.; OSTLUND, N.S. Modern Quantum Chemistry: Introduction to Advanced Eletronics Structure Theory. New York, Macmillan, 1982, p.446. 
88. MORGON, N.H.; CUSTODIO, R. Teoria do funcional de densidade. Química Nova, v.18, p.44-55, 1995.

89. YATES, P.C.; PATEL, B. Semiempirical molecular orbital calculations on dye molecules. Journal of Molecular Structure: THEOCHEM, v.315, p.117-122, 1994.

90. LUPAN, L. Correlation of molecular properties of some acridine and thiazine dyes in miscellar solution with their electronic structure. Revue Roumaine de Chimie, v.43, p.671-674, 1998.

91. GUILLAUMMONT, D.; NAKAMURA, S. Calculation of the absorption wavelength of dyes usinf time-dependent density-functional theory (TD-DFT). Dyes and Pigments, v.46, p.85-92, 2000;

92. HOMEM-DE-MELLO, P.; MENNUCCI, B., TOMASI, J.; DA SILVA, A. B. F. Cationic dye dimers: a theoretical study. Theoretica Chimica Acta, v.118, p.305-314, 2007.

93. MENEZES, P. F. C.; SIBATA, C.H.; JOHNKE,R.M.; ALLISON, R.R.; BAGNATO, V.S.; BONNERUP,C.; PERUSSI, J.R. Photodynamic therapy for Photogem and Photofrin using different lights wavelengths in 375 human melanoma cells.. Laser Physics Letters, v. 5, p. 1-6, 2007.

94. ALBERTS, B.; JOHNSON, A.; LEWIS, J.; RAFF, M.; ROBERTS, K.; WALTER, P. Biologia molecular da célula. Porto Alegre: Artmed, 2004, 4.ed.,p.470-478.

95. MENEZES, P.F.C. Estudos Espectroscópicos e Citotóxicos do Photogem Fotodegradado e dos Fotoprodutos Formados após Irradiação com Laser. São Carlos, 2006. Tese (Doutorado)-Instituto de Química de São Carlos, Universidade de São Paulo.

96. CORRÊA, J.C. Fotodegradação do photodithazine e citotoxicidade dos fotoprodutos formados após irradiação com laser. São Carlos, 2006. Dissertação (Mestrado)-Instituto de Química de São Carlos, Universidade de São Paulo. 
97. MELO, C.A.S., CARVALHO, V.C.M., BAGNATO, V.S., PERUSSI, J.R. Comparison of the effects of cationic and anionic porphyrins in tumor under illumination of argon ion laser, Laser Physics, v.12, p.1314-1319, 2002.

98. VALERIA CARDOSO DE MELO CARVALHO. Estudo dos efeitos de duas porfirinas hidrofílicas em células tumorais Hep-2 visando aplicação na terapia fotodinâmica do câncer. São Carlos, 2001. Dissertação (Mestrado) - Instituto de Química de São Carlos, Universidade de São Paulo.

99. MOSMANN, T. Rapid colorimetric assay for cellular growth and survival: Application to proliferation and cytotoxicity assays. Journal of Immunological Methods, v.65, p.55-63, 1983.

100. CHOU, T.C.; HAYBALL, M. CalcuSyn: Windows software for dose effect analysis. Cambridge: Biosoft, 1996.

101. DEWEY. T.G (Ed.). Biophysical and Biochemical Aspects of Fluorescence Spectroscopy. New York, Plenum Press, 1991, p.1-41.

102. LAKOWICA, J.R.; WEBER, G. Quenching of fluorescence by oxygen. Probe for structural fluctuations in macromolecules Biochemistry, v.12, p.4161-4170, 1973.

103. POOLER, J.P.; VALENZENO, D.P. Physicochemical determinants of the sensitizing effectiveness for photooxidation of nerve membranes by fluorescein derivatives. Photochemistry and Photobiology, v.30, p.491-498, 1979.

104. LEE, C.; YANG, W.; PARR, R. G. Development of the Colle-Salvetti correlationenergy formula into a functional of the electron density. Physical Review B, v.37, p.785-789, 1988.

105. MIEHLICH, B.; SAVIN, A.; STOLL, H.; PREUSS, H. Results obtained with the correlation energy density functionals of becke and Lee, Yang and Parr. Chemical Physics Letters, v.157, p.200-206, 1989.

106. BECKE, A. D. Density-functional thermochemistry. III The role of exact exchange. Journal of Chemical Physics, v.98, p.5648-5652, 1993. 
107. CANCÈS, E.; MENNUCCI, B.; TOMASI, J. A new integral equation formalism for the polarizable continuum model: Theoretical background and applications to isotropic and anisotropic dielectrics. Journal of Chemical Physics, v. 107, p. 3032-3041, 1997.

108. MENNUCCI, B.; CANCÈS, E.; TOMASI, J. Evaluation of Solvent Effects in Isotropic and Anisotropic Dielectrics and in Ionic Solutions with a Unified Integral Equation Method: Theoretical Bases, Computational Implementation, and Numerical Applications. Journal of Physical Chemistry B, v. 101, p. 10506-10517, 1997.

109. CANCÈS, E.; MENNUCCI, B. New applications of integral equations methods for solvation continuum models: ionic solutions and liquid crystals. Journal of Mathematical Chemistry, v. 23, p. 309-326, 1998.

110. FRISCH, M. J. ET AL. Gaussian 03, Revision B.04; Gaussian, Inc.: Pittsburgh, PA, 2003.

111. HOMEM-DE-MELLO, P.; MENNUCCI, B.; TOMASI, J. ; SILVA, A. B. F. The effects of solvation in the theoretical spectra of cationic dyes. Theoretica Chimica Acta, v. 113, p. 274-280, 2005.

112. HOMEM-DE-MELLO, P. Estudo teórico sobre corantes catiônicos e possíveis modelos que expliquem a interação com a argila do tipo montmorilonita. São Carlos, 2006. Tese (Doutorado)-Instituto de Química de São Carlos, Universidade de São Paulo.

113. HONORIO, K. M., \& DA SILVA, A. B. F. An AM1 study on the electron-donating and electron-accepting character of biomolecules. International Journal of Quantum Chemistry, v.95, p.126-132, 2003.

114. R.E.BRUNS; P.H.GUADAGNINI; A.A.SOUZA; Química. Nova, v. 19, p.148-155, 1996.

115. HyperChem(TM) Professional 7.51, Hypercube, Inc., 1115 NW 4th Street, Gainesville, Florida 32601, USA.

116. BARROS NETO, B.; SCARMINIO, I. S.; BRUNS, R. E. Planejamento de Otimização de experimentos, 2ª Ed, Ed. da Unicamp, Campinas; (1995); 32-34. 
117. W.R. WARE. Journal of Physical Chemistry, v.66, p.455, 1962. 